\author{
${ }^{1}$ Museum für Naturkunde der Humboldt-Universität zu Berlin, Berlin, Germany; ${ }^{2}$ Zoologisches Institut und Museum der Ernst- \\ Moritz-Arndt-Universität, Greifswald, Germany
}

\title{
The affinities of mites and ticks: a review
}

\author{
J. A. Dunlop ${ }^{1}$ and G. Alberti ${ }^{2}$
}

\begin{abstract}
Mites and ticks can be divided into two well-defined clades, Anactinotrichida and Actinotrichida, for which a recent work formalized a suite of putative autapomorphies and reciprocal differences. Whether they are sister-taxa - forming a monophyletic Acari - is more controversial. Earlier supporters of two independent origins for mites largely failed to demonstrate convincing synapomorphies between either of the two lineages and other arachnid orders; although recent work on reproductive biology revealed explicit characters of this nature. Furthermore, some of the characters proposed in support of a monophyletic Acari do not stand up to detailed scrutiny when compared with Arachnida in general. Effective morphological comparisons between mites and other arachnids are hindered by incompatible nomenclature and long-standing, mite-specific characters which are difficult to score for other arachnids. Furthermore, taxon-specific characters restricted to individual mite groups have sometimes been treated erroneously as 'typical' for all Acari. Here, previous hypotheses of mite affinities are reviewed. Historically, authors have debated whether mites are basal arachnids or highly derived. Excluding weakly supported early hypotheses, mites have been resolved - in whole or in part - as sister-group of all other Arachnida (based on tagmosis), closely related to Opiliones (based mostly on genital morphology), Palpigradi (based on controversial interpretations of limb morphology), Solifugae (based mostly on the mouthparts, but now perhaps also reproductive characters) and Ricinulei (based on hexapodal larvae and perhaps mouthparts). We cannot provide a final resolution here, but we aim to highlight important character sets which should be included in subsequent phylogenetic analyses, as well as useful areas for future investigations: particularly tagmosis and the nature of the gnathosoma.
\end{abstract}

Key words: Acari - Anactinotrichida - Actinotrichida - Arachnida - phylogeny

\section{Introduction}

Mites and ticks (Acari) are, with nearly 48,200 described extant species (Harvey 2002), the most diverse group of arachnids known. Their high species-level diversity is reflected in their extraordinary ancientness and morphological, behavioural and ecological disparity (e.g. Evans 1992; Moritz 1993; Alberti and Coons 1999; Coons and Alberti 1999; Walter and Proctor 1999), whereby the number of previously recognized 'orders' ranges from one (Acari), to seven or more (e.g. Evans 1992). Despite their abundance, and a wealth of literature about their classification, biology and economic significance, the affinities of mites remain poorly resolved. The most comprehensive recent attempt to elucidate relationships among Chelicerata - applying morphological and molecular data was forced to conclude that: 'The position of Acari is highly unstable to parameter change...' (Giribet et al. 2002, p. 25). Various authors, most notably Zachvatkin (1952) and van der Hammen (1989a and references therein), have even questioned whether mites are a natural group and some recent data (e.g. Alberti 2000) continues to draw their monophyly into question. A single origin for Acari has been defended, e.g. by Lindquist (1984) who concluded that it was most reasonable to assume monophyly based on the evidence available at that time. This important study, coupled with van der Hammen's rejection of parsimony and thus a tendency among later workers to downplay his conclusions, led to a priori assumptions of monophyly in cladistic analyses such as Shultz (1989, 1990) and Wheeler and Hayashi (1998). Specifically, Acari was scored by these authors as a single terminal taxon derived from a composite of morphologically disparate species.

As Alberti (2006) has once again demonstrated (see also Grandjean 1935, 1936a,b; Alberti 1980a,b; Lindquist 1984; Bernini 1986), there are two very distinct lineages of mites (Figs 1-6), for which we here adopt the names Anactinotrichida and Actinotrichida. Alternatives in the literature (e.g. Klompen et al. 2007) are, respectively, Parasitiformes s.l. and Acariformes. The composition and principal features of these two groups are outlined below and they express quite fundamentally different character sets reflecting both their internal and external anatomy (Figs 3-6), as well as their reproductive biology. While Lindquist stressed similarities between mites as a whole, Alberti (2006, tables 1-5) placed greater emphasis on the differences which characterize anactinotrichids and actinotrichids. The evidence accumulated by Alberti (2006 and references therein) strongly argues for the monophyly of both groups and for recognizing these two clades as taxa ('orders') of equal rank. Moves to treat Opilioacarida as a further, independent, lineage (e.g. Harvey 2002) were rejected they represent basal anactinotrichids - and the trend now is to test relationships of anactinotrichid and actinotrichid mites independently (e.g. Giribet et al. 2002). A further point of contention is whether mites are essentially a basal clade (or grade) which diverged early from the remaining chelicerates (e.g. Dugès 1834; Abendroth 1868; Thorell 1877), or highly derived and specialized animals, perhaps with affinities among the tracheate arachnids (e.g. Pocock 1893; Wagner 1895; Uchida 1966; Yoshikura 1975; Weygoldt and Paulus 1979). Precisely this point was made by Reuter (1909) which suggests the fundamental questions posed by earlier workers remain largely the same.

A number of factors have contributed towards these difficulties. Arachnology and acarology have developed for over a hundred years as almost separate disciplines. This has resulted in a poor exchange of ideas, few workers experienced in both mite and non-mite orders and divergent morphological terminologies (see van der Hammen 1976, 1980, 1989b for Acari) which potentially obscure homologous, and phylogenetically informative, characters. This is particularly true with 


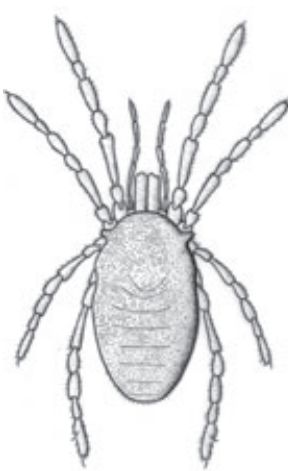

Opiliones

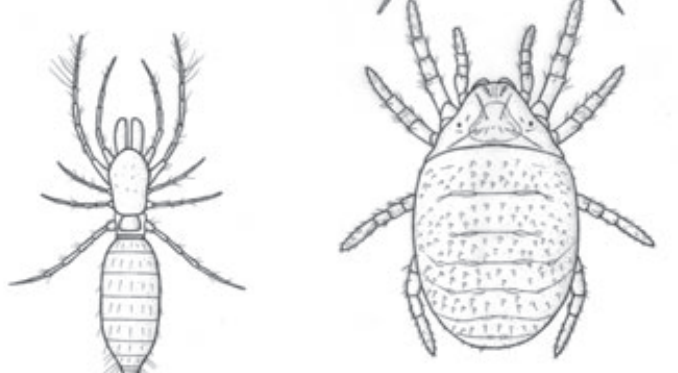

Palpigrad

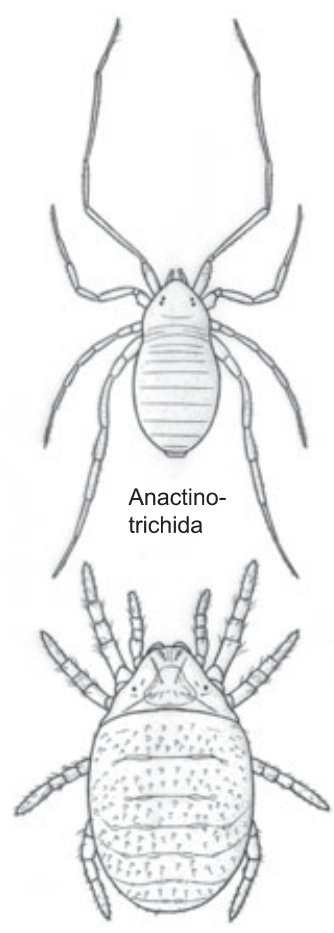

Actinotrichida
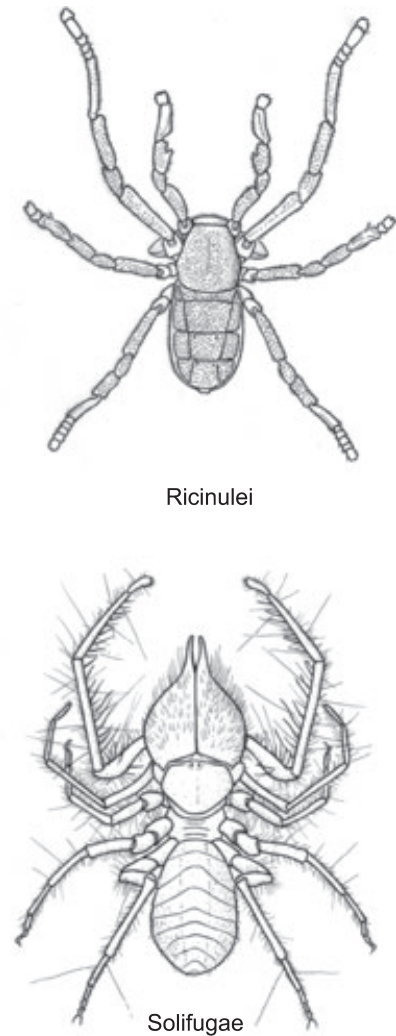

Fig. 1. Sketch reconstructions of putatively basal representatives of the two main mite lineages Anactinotrichida and Actinotrichida, and of the arachnid orders most commonly cited in the literature as being closely related to one or both of them: namely harvestmen (Opiliones, in particular Cyphophthalmi), palpigrades (Palpigradi), ricinuleids (Ricinulei) and camel spiders (Solifugae). After various sources; not to scale

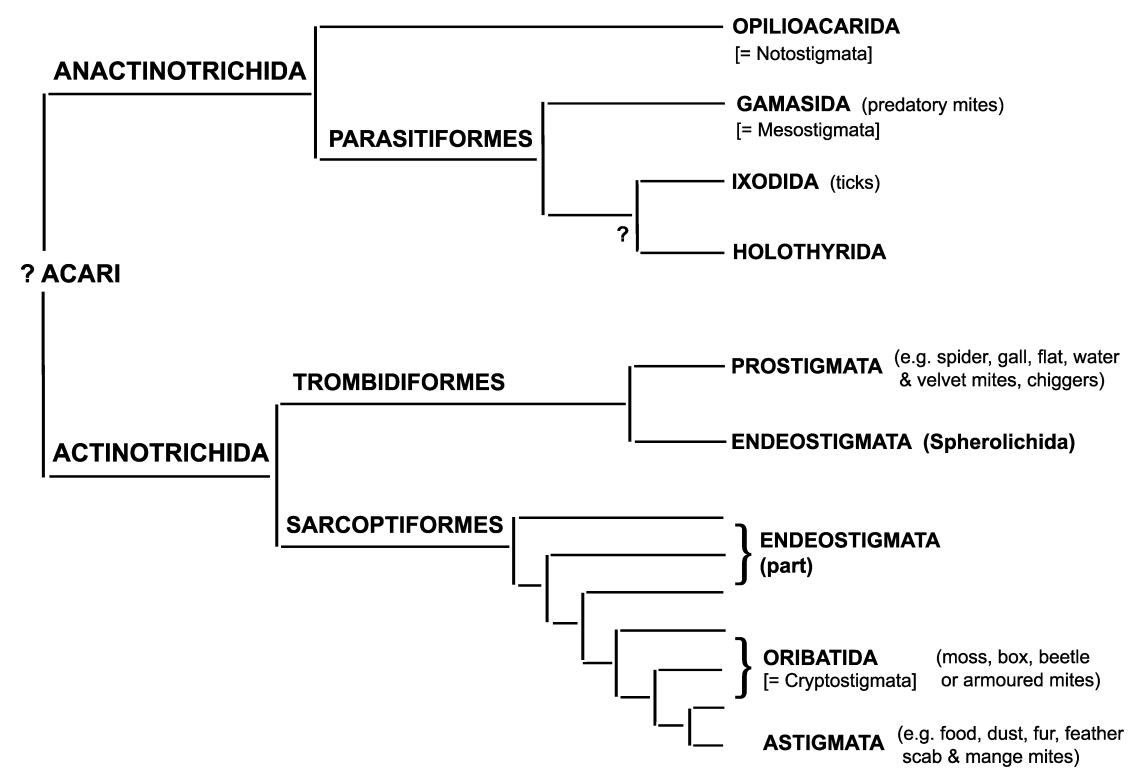

Fig. 2. A possible outline phylogeny for the mites illustrating major taxa (see text) and some of their alternative names and/or common members of the group. Cladogram derived largely from OConnor (1984); Lehtinen (1991), and that currently adopted in the Tree of Life project. Points of debate include whether holothyrids are the sistergroup of ticks (as shown; see Klompen et al. 2007) or gamasids. Note that endeostigmatids are probably not monophyletic and are currently split across two major lineages, forming a grade leading up towards the oribatids among the sarcoptiforms. Oribatids themselves also appear to resolve as a paraphyletic assemblage with respect to the astigmatics

respect to the mouthparts, including the all-important gnathosoma (see below) which is widely regarded as the best character supporting a monophyletic Acari. Given that some morphological terms traditionally had different meanings in different groups, van der Hammen (1980, 1989a) attempted to describe all Chelicerata using a standardized (largely acarological) terminology. His approach has not been widely adopted. Indeed, mites, or subgroups within the mites, are often defined by acarologists using characters or nomenclature which are difficult to apply to other arachnids (see also comments in Alberti 2006) like the lyrifissures, fundamental

(C) 2007 The Authors J Zool Syst Evol Res (2008) 46(1), 1-18 Journal compilation (c) 2007 Blackwell Verlag, Berlin setae, podocephalic canals, actinopilin, and Haller's and Claparède organs mentioned by Lindquist (1984). While these are often regarded as being of considerable significance for Acari they are rarely (if ever) scored in more wide-ranging phylogenetic analyses of Chelicerata (cf. Shultz 1989, 1990; Wheeler and Hayashi 1998; Giribet et al. 2002). This is presumably because these characters have been poorly studied, if studied at all, in non-acarine arachnids.

Alberti (2006) touched only briefly on the potential relationships of anactinotrichid and actinotrichid mites with respect to other arachnids. Here, we aim to complement that 
Fig. 3. Semi-schematic comparative drawings of a basal anactinotrichid (Opilioacarida: Neocarus sp.) (above) and an actinotrichid (Endeostigmata: Alycus sp.) mite (below), illustrating some of the major morphological differences between them in lateral section. Not to scale; see text for details
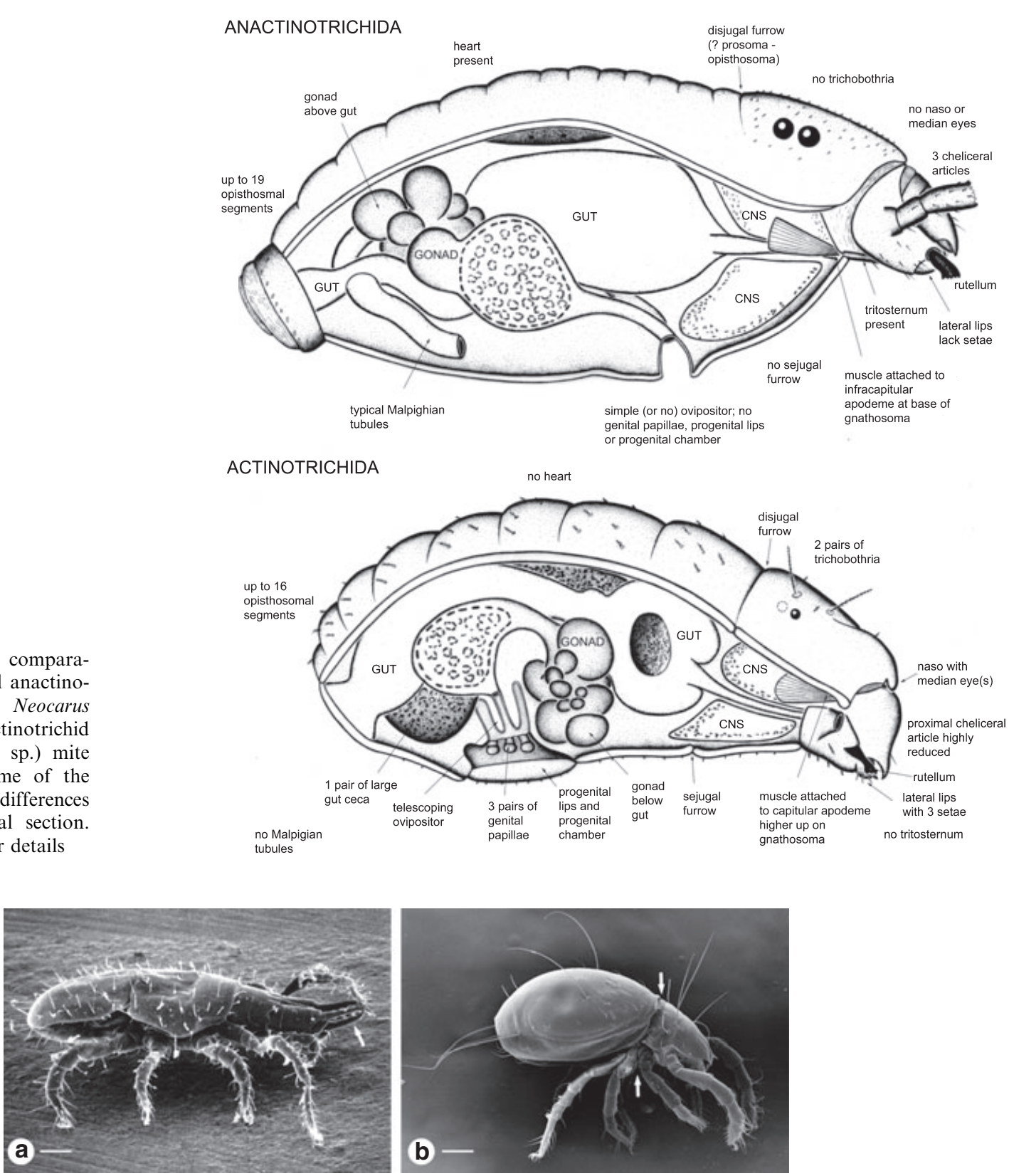

Fig. 4. Representatives of the two major groups of Acari, Anactinotrichida and Actinotrichida, in lateral view. (a) Rhodacarus sp. (Gamasida) a predatory anactinotrichid soil mite. Note the relatively large gnathosoma with (exceptionally) massive chelicerae. Note how the mobile digit articulates ventrally (arrow). Scale bar $=40 \mu \mathrm{m}$. (b) Collohmannia gigantea (Oribatida) a macrophytophagous actinotrichid soil mite. Note the distinct division of the body between the second and third pair of legs into a proterosoma and a hysterosoma via the sejugal furrow (indicated by arrows). Scale bar $=200 \mu \mathrm{m}$. (Modified from Alberti and Coons 1999)

work through a comprehensive review of the previous ideas about the origins and affinities of mites. We aim to assess, where possible, the characters offered in their support, and to do so from an interdisciplinary perspective. Acari, in whole or in part, have been placed as sister-group to all other arachnids, or have been allied (tenuously) to whip scorpions (Thelyphonida) and to harvestmen (Opiliones), camel spiders (Solifugae), palpigrades (Palpigradi) and in recent years particularly with ricinuleids (Ricinulei) (Fig. 1). Important summaries and reviews have been published by Reuter (1909); André and Lamy (1937); Woolley (1961); Lindquist (1984) and Bernini (1986). This present work builds on all of these. Since Bernini's study, there has been progress both in terms of the methods used to reconstruct phylogeny and in the elucidation of new characters and new hypotheses (e.g. Shultz 1989, 1990; Alberti 1991, 2000, 2006; Dunlop 1996, 2000, 2006; Giribet et al. 2002). We cannot address every suggestion in the extensive literature, nor can we provide a final answer here, but we hope to stimulate new research by providing a solid starting point for future investigations of mite relationships.

\section{Early work}

Mites have been known since antiquity. Although it is not clear which species he had in mind, Aristotle introduced the name 'akari' for them. By the 16th century, the word can be

(C) 2007 The Authors J Zool Syst Evol Res (2008) 46(1), 1-18 Journal compilation (C) 2007 Blackwell Verlag, Berlin 

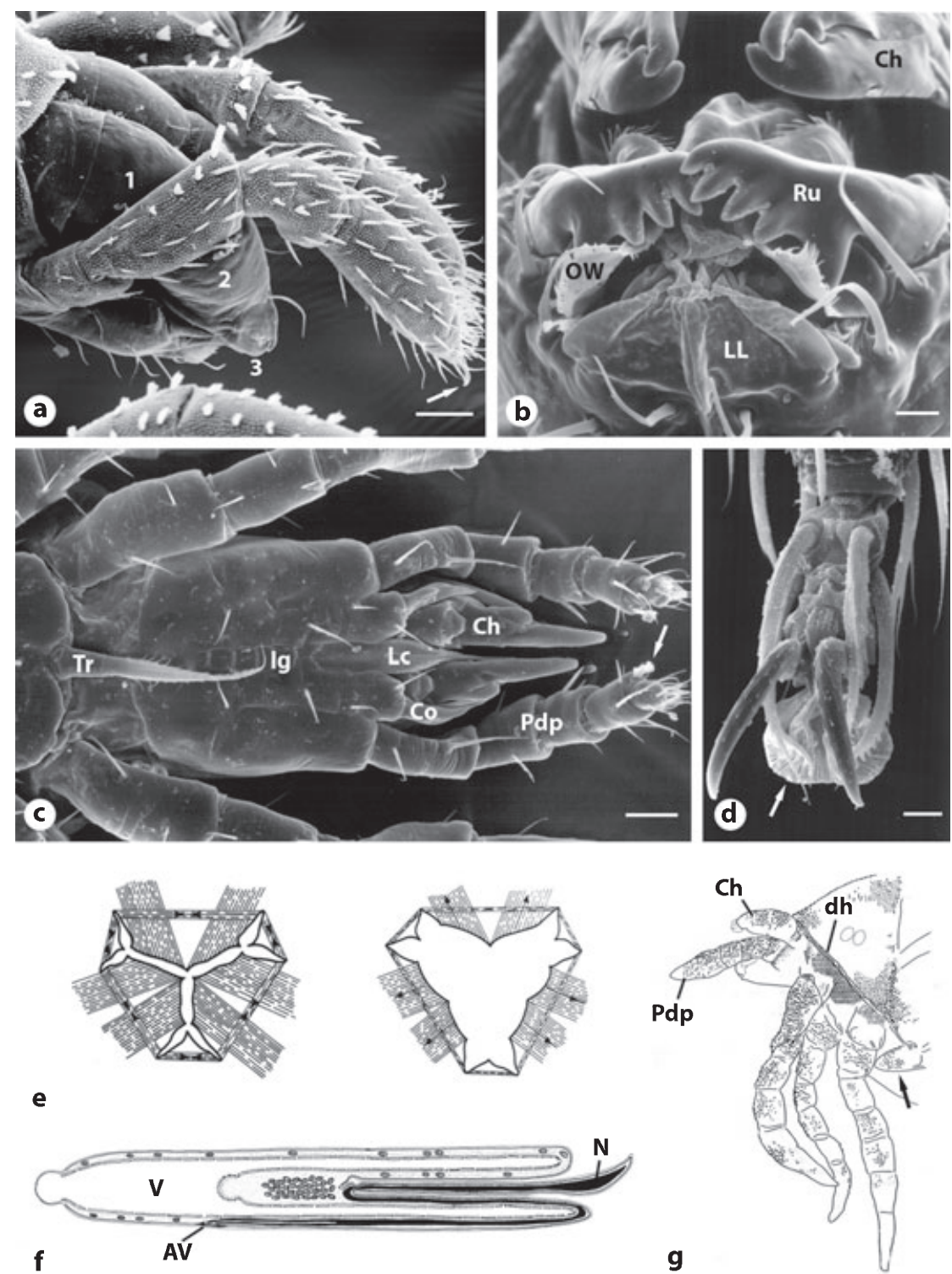

Fig. 5. Some peculiarities of Anactinotrichida. (a) Dorso-lateral view of the gnathosoma of Neocarus texanus (Opilioacarida). Note the threearticled chelicera (numbered 1-3) and pedipalpal apotele (arrow). Scale bar $=60 \mu \mathrm{m}$. (b) Frontal view of the infracapitulum of Neocarus texanus. Scale bar $=10 \mu \mathrm{m}$. (c) Ventral view of gnathosoma of Rhodacarus sp. (Gamasida). Arrow indicates apotele. Scale bar $=20 \mu \mathrm{m}$. (d) Ambulacrum of leg II of Neocarus texanus. Note two claws and a pulvillus (arrowed). Scale bar $=5 \mu \mathrm{m}$. (e) Drawing of cross sections through the pharynx of Argas persicus (Ixodida) in both the constricted (left) and dilated (right) state. Arrows indicate action of muscles; note the basically Y-shaped lumen of the pharynx in transverse section. (f) Reconstruction of sperm cell of Neocarus texanus demonstrating their complex, vacuolated type of sperm. (g) Lateral view of anterior part of a prelarva of Neocarus texanus. Note rudimentary leg IV (arrowed). (a-d) modified from Alberti and Coons (1999); (e) modified from Robinson and Davidson (1913); (f) modified from Alberti (1980a); (g) modified from Klompen (2003). AV, acrosomal vacuole; $\mathrm{Ch}$, chelicera; Lc, laciniae (homologues of part of lateral lips); Co, corniculus (homolog of rutellum?); dh, moulting line; Ig, infracapitular gutter; LL, lateral lips; N, nucleus; OW, With's organ (a flap-like structure only known from Opilioacarida); Pdp, pedipalp; Ru, rutellum; $\mathrm{Tr}$, tritosternum (homologuous with the sternapophyses of Opilioacarida); V, vacuole

found in its Latinized form 'acari' and is clearly the source of Linnaeus' genus name Acarus; one of his so-called 'Insecta aptera'. The first, tentative steps on the road towards modern classification were outlined in some detail by Vizthum (1943, pp. 4-31 and references therein). In brief, early naturalists following Linnaeus frequently mixed up the known genera of mites with such diverse groups as crustaceans, the common sea spider Pycnogonum, small beetles, ectoparasitic insects, and cyphophthalmid and trogulid harvestmen. William Elford Leach (1790-1836) deserves credit for recognizing mites as an arachnid order-here for the first time, as a natural group with

(C) 2007 The Authors J Zool Syst Evol Res (2008) 46(1), 1-18 Journal compilation (c) 2007 Blackwell Verlag, Berlin no erroneous taxa assigned to it - for which he proposed the name Monomerosomata Leach, 1815. Four years later, Leach (1819) replaced this ordinal name with a class Acari; although the credit for naming the taxon is usually given to Christian Ludwig Nitzsch (1782-1837) who introduced essentially the same name a year earlier as Acarina Nitzsch, 1818. The scheme of Leach did not stop some subsequent authors continuing to introduce non-mites into the Acari, the usual suspects being water bears (Tardigrada) and sea spiders (Pycnogonida: Pantopoda), but the mites were now on their way to being a definable and recognizable group. 

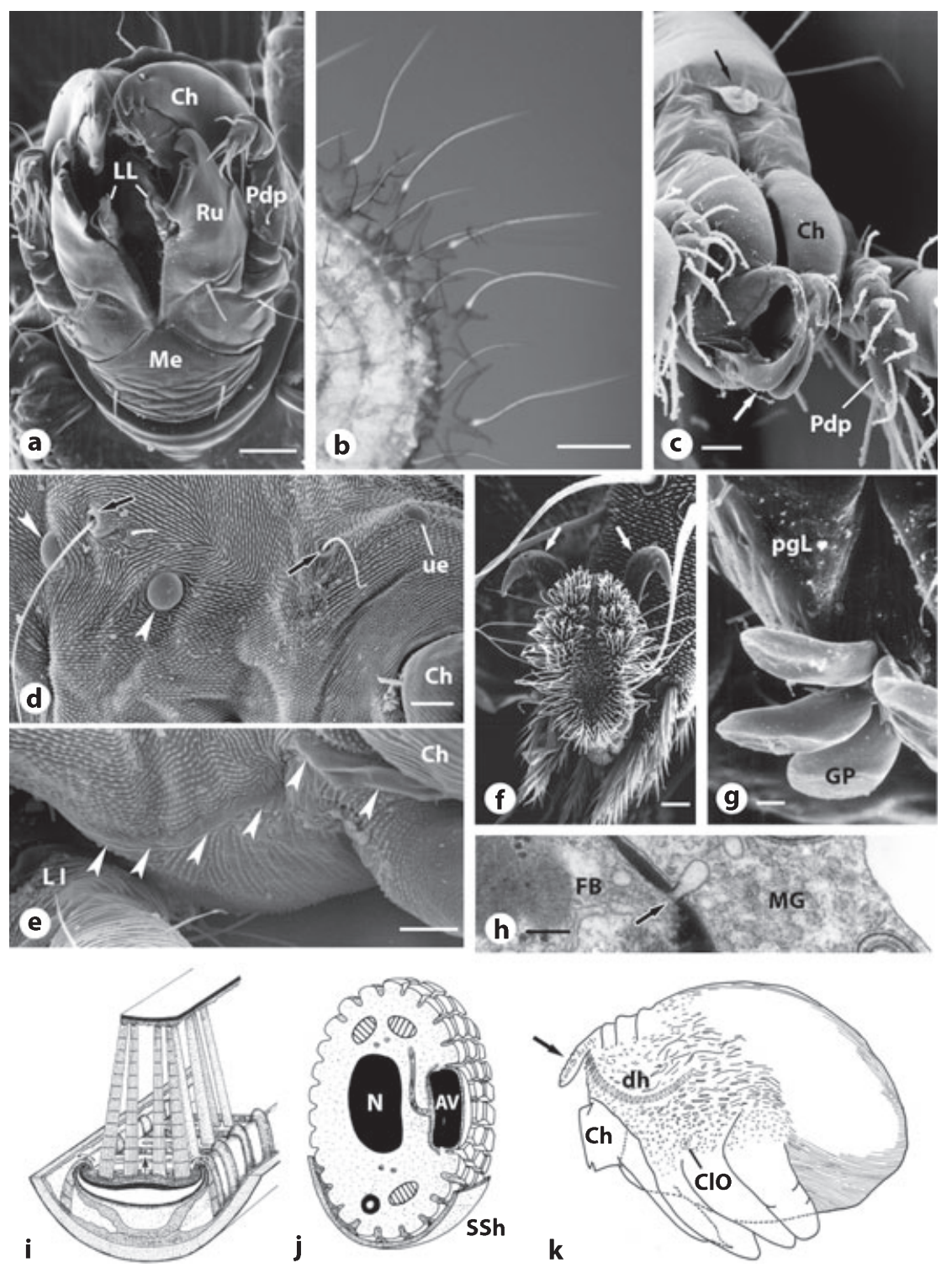

Fig. 6. Some peculiarities of Actinotrichida. (a) Fronto-ventral view of the gnathosoma of Eulohmannia ribagai (Oribatida). Note lateral lips with three setae and absence of an infracapitular gutter. Scale bar $=20 \mu \mathrm{m}$. (b) Detail of dorsal aspect of tritonymph of Cepheus dentatus (Oribatida) under polarized light. Note birefringent setae; the classic actinotrichid feature. Scale bar $=100 \mu \mathrm{m}$. (c) Dorso-frontal view of gnathosoma of Rhagidia sp. (Prostigmata). Black arrow indicates the so-called naso, probably an acron-derivative. White arrow points to ventrally articulating mobile digit of the massive chelicera. Scale bar $=20 \mu \mathrm{m}$. (d) Detail of right side of dorsal proterosoma of Cyta latirostris (Prostigmata). Black arrows highlight trichobothria, white arrowheads the lateral eyes; note also the unpaired eye. Scale bar $=20 \mu \mathrm{m}$. (e) Detail of lateral part of proterosoma of Cyta latirostris. Arrowheads indicate podocephalic canal running from leg I to the base of the chelicerae. Scale bar $=10 \mu \mathrm{m}$. (f) Ambulacrum of Neomolgus littoralis (Prostigmata) showing two claws (arrowed) and an empodium between them. Scale bar $=10 \mu \mathrm{m}$. $(\mathrm{g}$ ) Genital opening of Hypochthonius rufulus (Oribatida) with three pairs of genital papillae protruding from the progenital chamber through the slightly opened progenital lips. Scale bar $=5 \mu \mathrm{m}$. (h) Hydrozetes lemnae (Oribatida). Finger-like process (arrow) protruding from fat body cell through basal lamina of midgut epithelium into midgut cell. Scale bar $=0.25 \mu \mathrm{m}$. (i) Reconstruction of pharynx of Archegozetes longisetosus (Oribatida). Note the crescent-shaped (not Y-shaped) lumen of the transversely sectioned pharynx and distinctly differentiated cuticle and muscle arrangement. Arrows indicate movements of muscles and roof of pharynx during dilation. (j) Drawing of a sperm cell of Cyta latirostris. Secretion sheath partly removed. (k) Lateral view of prelarva of Cyta latirostris. Arrow indicates so-called naso. (a, c- $\mathrm{h}$ ) modified from Alberti and Coons (1999); (i) modified from Alberti et al. (2003); (j) modified from Alberti (1980b); (k) modified from Alberti (1975). AV, acrosomal vacuole; Ch, chelicera; dh, molting line; $\mathrm{ClO}$, organ of Claparède; FB, fat body cell; GP, genital papilla; L I, leg I; LL, lateral lips; Me, mentum (i.e. ventral part of infracapitulum); Mg, midgut cell; N, nucleus; Pdp, pedipalp (without apotele); pgL, progenital lips; ue, unpaired eye

\section{Mites as basal arachnids?}

Within the arachnids, Antoine Louis Dugès (1797-1838) recognized two subclasses: Hologastres Dugès, 1834 (or Acularistes), effectively restricted to mites and ticks, and Tomogastres Dugès, 1834 (or Aranulistes), incorporating all other arachnids plus the sea spiders (Dugès 1834, p. 10).
Essentially, Dugès argued that mites can be separated from all other arachnids based on gross morphology. Abendroth (1868) again recognized mites as essentially the sister-group of all other arachnids (this time without sea spiders) and used Dugès' name Tomogastra (nom. trans.) for the non-mite clade; note that Dunlop (2002) erroneously assigned authorship of this

(C) 2007 The Authors J Zool Syst Evol Res (2008) 46(1), 1-18 Journal compilation (C) 2007 Blackwell Verlag, Berlin 
taxon name to Abendroth. Essentially, mites were resolved by Abendroth to a basal position between the tardigrades and all non-acarine arachnids. While similarities between mites and tardigardes appear superficial and based only on small body size, 'tomogastrid' arachnids are not without morphological support. For example, Abendroth noted that mites do not generally have the clear prosoma-opisthosoma tagmosis typical for other arachnids and that segmentation of the abdomen is usually indistinct (Fig. 4). He further noted that mites, with their hexapodal larvae, do not hatch with a fully adult morphology (Figs 5g and 6k). Ricinuleids also have hexapodal larvae, but were only recognized as a distinct order in 1887 , having been discovered as fossils some years earlier (see e.g. Selden 1992). Thus in 1868 tomogastrid (i.e. non-mite) arachnids could be defined on a putatively apomorphic form of precocious development in which all instars had the full complement of adult appendages (but see the Acaromorpha hypothesis below).

Dubinin $(1957,1959)$ also placed mites as essentially basal arachnids in his summary of arachnid palaeontology, referring them to a separate class Acaromorpha Dubinin, 1957; a name later adopted (see below) for (Acari + Ricinulei). Although the fossil record cannot prove or disprove a phylogeny (Shultz 1994), it is interesting to note that the oldest putative fossil of any arachnid is currently an oribatid mite from the Ordovician (earliest Arenig: c. 480-485 Ma) of Sweden (Bernini et al. 2002). Its extreme age and the fact that it dates from a time when life on land may not have been fully established render the find controversial. Indeed, the authors drew comparisons with modern (intertidal) Ameronothridae and suggested that this mite may not have been fully terrestrial. If it can be shown not to be a contaminant, then this ancient oribatid predates the oldest non-mite-arachnids from the mid-late Silurian by some 40-45 Ma. In any case, this early fossil record refers only to actinotrichid mites (in particular trombidiform and oribatid mites). In contrast, Anactinotrichida are recorded no earlier than the Upper Cretaceous (an argasid tick; Klompen and Grimaldi 2001). The only opilioacarid fossil known was described from Baltic amber (Paleogene: Eocene; Dunlop et al. 2004).

Furthermore, some modern phylogenetic results, including molecular data (cf. Giribet et al. 2002, figs 5, 7) also recovered mites in a basal position to other arachnids under some parameters of analysis (see Molecular data); a position which seemed unexpected or unintuitive, but which could actually prove to be more congruent with the fossil record. Alternately, if one wishes to argue that mites are highly derived arachnids (cf. Weygoldt and Paulus 1979), then the Swedish fossil would delimit the minimum age of cladogenesis. It implies radiation of the arachnids into their major (?'pulmonate' and 'tracheate') lineages prior to the early Ordovician; presumably in a fully marine environment. Kraus (1976), for example, postulated a radiation of arachnids before they came onto land.

\section{Are mites arachnids at all?}

This is not an entirely facetious question, especially given that mite and non-mite literature remain largely independent of one another. In an early arachnid phylogeny, Thorell (1877) effectively placed mites as a sister-group to the remaining arachnids and the Mandibulata (i.e. insects, myriapods and crustaceans). In this paper camel spiders were bizarrely grouped with insects on account of their extensive tracheae.

(C) 2007 The Authors J Zool Syst Evol Res (2008) 46(1), 1-18 Journal compilation (C) 2007 Blackwell Verlag, Berlin
Bernard (1892) interpreted mites as essentially progenetic arachnids (i.e. retaining many characters at the larval stage of development), as betrayed by their small size, often reduced number of segments and aspects of their supposedly incompletely developed internal anatomy. This is perhaps a reasonable starting hypothesis (but see Reuter 1909 for criticisms), but Bernard then went on to argue that the prosomal tracheae of certain mites supported a strange transition series from juvenile arachnids (probably spiders), to mites, to insects.

A number of influential acarologists, including Haller (1881); Oudemans (1885) and Canestrini (1891), effectively treated Acari as a distinct class of arthropods, separate from the other arachnids. In some ways this reflects the views of, say, Dugès or Abendroth and such ideas continued well into the 20th century (see e.g. Hoffmann 1988) where they may be partly responsible for the eventual split into arachnology and acarology as largely independent disciplines. Thor (1928) again outlined some fairly fundamental differences between mites and other arachnids in terms of development, tagmosis, mouthparts, limb structure, and the respiratory and reproductive systems; deriving mites directly from worm-like ancestors. The hypothesis of Thor, and earlier workers who argued from a similar perspective, can be largely rejected for simply accumulating autapomorphies as evidence of 'uniqueness' - a common failing of pre-cladistic classifications. No convincing synapomorphies have been proposed which will recover mites outside the Euchelicerata (Weygoldt and Paulus 1979). Obvious euchelicerate characters in mites include the chelate chelicerae followed by the pedipalps and four pairs of walking legs (at least in adult mites), and a genital opening on the second segment behind the last pair of walking legs (Figs 3 and 4).

\section{A natural group?}

The possibility that Acari is not monophyletic has been a consistent, and controversial, theme for much of the history of work on these animals. In terms of phylogenetic systematics this question is not trivial. Is there a single sister-taxon of all Acari, or are mites simply a small-bodied grade of organization in which different groups resolve closest to different, possibly quite unrelated, arachnid orders? Historically, the diversity of mite body plans led some early authors to question monophyly. For example, C. L. Koch (1844) felt that ticks (Ixodida) were so unusual that they must have originated separately from the other mites, and even the other arachnids. Mégnin (1876) regarded gamasid mites in particular as transitional forms between arachnids and insects. Schulze (1932) attempted to derive ticks directly from the extinct arachnid order Trigonotarbida; at that time known under the older name Anthracomartida. This ingenious hypothesis was based on the festoons around the edge of the hard tick body, which Schulze compared with the lateral plates of the divided opisthosomal tergites in trigonotarbids. Other characters clearly show that trigonotarbids belong to the so-called tetrapulmonate arachnids (see below); thus, comparisons with ticks seem superficial at best.

\section{Two major lineages}

Early work on classification within Acari was reviewed in detail by Vizthum (1943). Of particular importance is the system of Enzio Reuter (1867-1951), who excluded opilioacarids from Acari while recognizing four principal suborders 
among the rest: Parasitiformes, Trombidiformes, Sarcoptiformes and Eriophyiformes. Reuter's (1909) scheme remains largely valid, although eriophyiforms were originally diagnosed incorrectly on a blind-ending gut and are now included among the trombidiforms (cf. Lindquist and Amrine Jr 1996). Modern classifications - such as that adopted in the Tree of Life project - recognize Opilioacarida, Parasitiformes, Trombidiformes and Sarcoptifomes as the major systematic divisions (Fig. 2; Coddington et al. 2004). In detail, Opilioacarida are rare, fairly large mites, widely perceived as 'primitive' through their retention of up to six eyes and distinct abdominal segmentation. Parasitiformes embrace the rare holothyrids, the mostly predatory gamasids and the ectoparasitic ticks. Trombidiformes mostly contains a diversity of prostigmatic mite clades, including groups like snout mites, spider mites, quill mites, gall mites, velvet mites, chiggers and water mites, as well as part of the endeostigmatids. Finally, Sarcoptiformes encompass the remaining endeostigmatid, oribatid and astigmatic mites. Like endeostigmatids, oribatids are probably paraphyletic, whereby astigmatics may be a derived oribatid lineage (OConnor 1984; Norton 1998). Further discussions of higher classification, alternative taxon names, defining characters and additional background literature can be found in Lindquist (1984) and Bernini (1986) or in textbooks such as Krantz (1978), Evans (1992), Moritz (1993), Alberti and Coons (1999) and Walter and Proctor (1999).

François Grandjean (1882-1975) was of immense influence on the history of mite research, arguing (e.g. Grandjean 1935, $1936 a, b)$ for a fundamental division of the mites into three lineages. His Actinochitinosi (= Trombidiformes + Sarcoptiformes) was characterized by birefringent setae containing actinochitin (Fig. 6b). By contrast, Anactinochitinosi (= Parasitiformes s.1.) lack this birefringence. Opilioacarid mites were thought by Grandjean $(1936 b, 1970)$ to occupy an intermediate position between the two, but probably closer to anactinochitinosids. Note that this 'actinochitin', which causes the birefringence, was later renamed 'actinopilin' on the grounds that this is not truly chitinous in nature. There have been a few attempts (but see Zachvatkin 1952) to score this supposedly crucial birefringence character for other arachnid orders. Even Grandjean (1970) eventually became more circumspect about the significance of birefringence, suggesting that the character could be homoplastic even within actinochitinous mites. It should also be stated that Grandjean did not actually propose a diphyletic origin for mites [see e.g. Lindquist (1984) - contra Woolley (1961, p. 265)]. The names of these groups were subsequently modified to Anactinotrichida Grandjean in van der Hammen, 1961 and Actinotrichida Grandjean in van der Hammen, 1961 (the latter with birefringent setae) respectively. Recent works (Alberti 1980a,b; Lindquist 1984; van der Hammen 1989a) have supported Grandjean's basic division into two major lineages and almost invariably include Opilioacarida within the Anactinotrichida as the most basal member of this clade.

Alberti (2006) summarized modern support for this division, proposing 77 characters which potentially differentiate these lineages from one another (see also Alberti 1980a,b, 1991, 2000; Alberti and Peretti 2002; Alberti and Michalik 2004). Of these, some characters are not found in all members of their respective groups and further work is required in some cases to resolve between plesiomorphic and apomorphic states, and thus their potential for diagnosing clades. The most significant and unequivocal characters are outlined below. Further details and descriptions can be found in (Alberti 2006 and references therein). Recently, Murrell et al.'s (2005) molecular data also recovered Acariformes (= Actinotrichida) as monophyletic and they stated (p. 387) that: 'Opilioacariformes and Parasitiformes are more closely related to each other than either of them is to the Acariformes'. The same was found in a more recent study based on rRNA published by Klompen et al. (2007). Thus, their studies support Anactinotrichida (including Opilioacarida and Parasitiformes s. str.) as the second major lineage of Acari; as outlined in traditional studies of morphology (e.g. Evans et al. 1961; van der Hammen 1961, 1977a; Alberti 1980a,b; Lindquist 1984; Bernini 1986).

\section{Anactinotrichida (Opilioacarida + Parasitifomes)}

Anactinotrichid mites (Fig. 3) do not have (1) birefingent setal structures [a weak birefringence has also been reported from some thick cuticular structures of setigenous origin in Opilioacarida, but as was discussed by Grandjean (1970) and Lindquist (1984), the entire character was of poor value with respect to phylogenetic considerations; see above], (2) a sejugal furrow dividing the body ventrally between the second and third pair of legs, (3) a protruding naso (with eyes) at the front of the proterosoma, (4) supracoxal (or laterocoxal) setae of the pedipalps and (5) podocephalic canals. The body (6) has up to 19 somites in current interpretations and the sternal area (7) is broad and surrounded by mobile coxae, except for ticks in which coxae are not articulated into the body; instead they are surrounded by weakly sclerotized and flexible circumcoxal integument. In any case, the coxal elements are not fused or integrated with sternal elements as is the case in Actinotrichida. The gnathosoma (8) lacks retractor muscles inserting on the capitular apodeme, (9) is divided ventrally by a sub- or infracapitular gutter associated plesiomorphically with sternapophyses (Fig. 5c) or a tritosternum, (10) lacks a dorsal median salivary duct, and (11) setae on the lateral lips. The chelicerae (12) distinctly express three articles (Fig. 5a) and the pedipalp (13) has a terminal apotele (in Opilioacarida; probably the plesiomorphic state; Fig. 5a) or a subterminal apotele (most other anactinotrichid mites). The mouth (14) is triangular (three lips), the preoral cavity (15) has dilator muscles, the pharynx (16) is fundamentally triangular in crosssection (Fig. 5e) and works (17) by peristalsis. The midgut epithelium (18) lacks finger-like processes of the fat body and Malpighian tubules (19) are present. The genital opening (20) is a simple transverse slit, there are no genital papillae (21) and a progenital chamber is also absent, the gonad (22) is plesiomorphically located dorsally, dividing spermatocytes (23) show distinctive tubular invaginations at cytoplasmic bridges, the testis (24) lacks glandular tissue, and the spermatozoa (25) are complex and plesiomorphically vacuolated (Fig. 5f). The larvae lack Claparède organs (26) (Fig. 5g).

\section{Actinotrichida (Trombidiformes + Sarcoptiformes)}

Actinotrichid mites, by contrast (Fig. 3), have (1) birefrigent setal structures (Fig. 6b), (2) a body divided into a proterosoma and hysterosoma (Fig. 4b) by the sejugal furrow, (3) a distinct naso at the front of the proterosoma (Fig. 6c) associated with median eyes (Fig. 6d), (4) supracoxal setae above the bases of the pedipalps and first legs - according to Johnston (1982) there are supracoxal setae on coxae I and II in the anactinotrichid Opilioacarida; however, these setae were

(C) 2007 The Authors J Zool Syst Evol Res (2008) 46(1), 1-18 Journal compilation (C) 2007 Blackwell Verlag, Berlin 
interpreted differently by van der Hammen (1989a) who called them laterocoxal setae and stated that such setae are lacking on the palpal coxae - and (5) a podocephalic canal system running to the gnathosoma from the coxal glands (Fig. 6e) opening above the first leg pair. The body (6) has no more than 16 somites based on current interpretations and the sternal area (7) is narrow and largely occupied with immobile coxae (epimera sensu van der Hammen). The gnathosoma (8) bears retractor muscles inserting on the capitular apodeme, (9) lacks a sub- or infracapitular gutter and sternapophyses or a tritosternum, (10) possesses a more or less distinct dorsal median salivary duct and (11) setae on the lateral lips (Fig. 6a). The proximal cheliceral article (12) is largely reduced and the pedipalps (13) lack an apotele. The mouth (14) is plesiomorphically quadrangular (four lips), the preoral cavity (15) lacks musculature, the pharynx (16) is crescentic in crosssection (Fig. 6i) and works (17) by a 'flip-flop' mechanism. The midgut epithelium (18) has distinctive, finger-like invasions of the fat body (Fig. 6h), but Malpighian tubules (19) are absent. The genital opening (20) is complex and covered by longitudinal progenital lips (Fig. 6g), genital papillae (21) (Fig. 6g) are present within the progenital chamber, the gonad (22) is plesiomorphically located ventrally, the testis (23) possesses glandular tissue, the spermatocytes (24) lack invaginations at cytoplasmic bridges, and the spermatozoa (25) are simple (Fig. 6j) and never vacuolated. The larvae and prelarvae bear Claparède organs (26) (Fig. 6k).

\section{Actinochaeta and Actinoderma}

The presence of two major mite lineages thus seems beyond question, but are they sister-taxa? In his posthumous 1952 study, Aleksey A. Zachvatkin explicitly proposed that mites were diphyletic, with two independent origins. Actinotrichid mites were placed closest to Solifugae and Palpigradi (Fig. 1) as part of a superorder Actinochaeta Zachvatkin, 1952. This taxon also included Schizomida and Pseudoscorpiones and, as the name implies, was essentially defined as arachnids with birefringent actinopilin sensu Grandjean. Other characters elaborated in support of 'actinochaete' arachnids included the presence of a proterosoma tagma (i.e. a 'head' region bearing only four pairs of appendages) and coxal glands. By contrast, anactinotrichid mites were placed in a superorder Actinoderma Zachvatkin, 1952 along with Araneae (spiders), Thelyphonida (whip scorpions), Opiliones (harvestmen), Ricinulei (Fig. 1) and the extinct Trigonotarbida. This group was defined by the absence of actinochitin, although Karg (2006), for example, regarded this as the plesiomorphic retention of an early ontogenetic condition (i.e. all arachnids start life without actinochitin) and thus a poor character to define a clade. Other characters of 'actinoderms' included a prosoma-opisthosoma tagmosis and the supposed absence of coxal glands. In fact, the latter character is incorrect as cited by Zachvatkin and anactinotrichid mites, for example, do have coxal glands (e.g. Moritz 1993; Alberti et al. 1996) - as do Opiliones, Araneae, Ricinulei and Uropygi - albeit in a modified form in some anactinotrichid groups.

\section{Van der Hammen's hypotheses}

Another figure of importance in acarine (and arachnid) higher systematics was Leendert van der Hammen (born 1921). In a series of comparative papers on arachnid morphology begin-

(C) 2007 The Authors J Zool Syst Evol Res (2008) 46(1), 1-18 Journal compilation (C) 2007 Blackwell Verlag, Berlin ning in the late 1960s (summarized in van der Hammen 1989a), he presented the strongest case to date for a diphyletic origin of Acari. After challenging the homology of the gnathosoma on the grounds of different musculature and other features (see also characters 8-10 above), mites were divided into their two main groups, each of which was supposed to be related to two of the rarest orders of extant arachnids. Anactinotrichida were placed closest to Ricinulei (Fig. 1) in a taxon Cryptognomae van der Hammen, 1977a; Actinotrichida were placed closest to Palpigradi (Fig. 1) as Epimerata van der Hammen, 1977a.

\section{Cryptognomae}

Ricinuleids are strange and slow-moving creatures found in caves or leaf litter, under logs and inside fallen bark of trees (Moritz 1993; G. Giribet, personal communication) whose biology remains poorly known. Their autapomorphies include a movable plate, the cucullus, which covers the mouthparts, a unique sperm transfer device on leg 3 of the males and an extremely thick cuticle. They also have a complex coupling device between the prosoma and opisthosoma and longitudinally divided opisthosomal tergites; characters, apparently, shared with the extinct trigonotarbids (see below). van der Hammen (1977a, 1989a) argued that Anactinotrichida were most closely related to Ricinulei based principally on: (1) a movable gnathosoma (convergent with that of actinotrichid mites), (2) no median eyes and one to three pairs of lateral eyes - in fact all extant ricinuleids are blind, but fossil taxa retain two pairs of lateral eyes (Selden 1992), (3) one to four pairs of tracheal stigmata - ricinuleids have only one (prosomal) pair, (4) absence of trichobothria, (5) a pedipalp without a free coxa and (6) a tendency to fuse the pedipalpal tibia and tarsus. As well as being defined (in part) on evolutionary 'trends' and on variable or reductive character states, Cryptognomae also suffers from being diagnosed on what can now be recognized as plesiomorphies, such as two 'ancestral' trochanters in legs 3 and 4. Shultz (1989) reformulated this character as a plesiomorphic divided femur based on detailed studies of limb musculature. Perhaps, the best support for van der Hammen's hypothesis is his proposal that the gnathosomal musculature of Anactinotrichida and Ricinulei is the same; i.e. the retractor muscles do not insert on the capitular apodeme, but insert at a deeper position at the base of the gnathosoma (Fig. 3). This assumes Ricinulei have a bona fide gnathosoma. Further unequivocal synapomorphies for Cryptognomae are difficult to find, although numerous other authors have treated all Acari as the sister group of Ricinulei (see the Acaromorpha hypothesis below).

Note that the prelarvae and larvae of Opiloacarida (in contrast to those of Actinotrichida) have a rudimentary pair of fourth legs (Alberti 2006), which is also present in larvae of Ricinulei (Pittard and Mitchell 1972), while holothyrid mite larvae have also been reported with a fourth pair of legs (Klompen 1992).

\section{Epimerata}

Palpigradi are a rare group of tiny, poorly sclerotized arachnids which lack eyes and respiratory organs in the form of book-lungs or tracheae, although their ventral sacs have sometimes been assigned a respiratory function. A number of authors have regarded palpigrades, or at least an animal with this grade of organization, as 'primitive' arachnids (e.g. Savory 
1971). It is fair to say that palpigrades do express a suite of probably plesiomorphic character states, such as chelate chelicerae with three articles, a postanal telson and three claws on the legs and pedipalps. van der Hammen (1977a,b, 1989a) placed Actinotrichida closest to Palpigradi - noting the fact that some members of both groups live in interstitial zones. This might be evidence in both of an earlier transition from water onto land. Condé (1996) commented on the fact that both groups are (or include) small animals which could have come onto land via soil interstices (see also Walter and Proctor 1999). This is, of course, not explicit support for Epimerata in a phylogenetic sense, although more generally Bernini et al.'s (2002) fossil oribatid from a possibly interstitial environment is interesting in this context. Central to this Epimerata taxon is van der Hammen's (1977b) controversial hypothesis that arachnids effectively lack leg coxae in their ground-pattern and that arachnid coxae in general developed relatively late from the outgrowths of prosomal sternites: the so-called 'epimera'. Using articulation patterns as markers, he concluded that the most proximal limb articles in acariform mites and palpigrades was a trochanter, and that the putative absence of a coxa in these groups was an ancestral arachnid character. This process of coxal formation was supposed to be at a more advanced stage in other arachnid lineages, such that even if van der Hammen were correct, his 'epimerate' mites and palpigrades would be united by a plesiomorphic grade of organization.

Methodology aside, the whole rationale behind the transition series from sternite to coxa is not easy to follow and this sequence of limb evolution clearly relies on 'paper animals' in the form of hypothetical intermediate stages (van der Hammen 1989a, fig. 7). At least for palpigrades, Shultz (1989) found no reason to regard the coxa as absent based on their limb musculature. More recently, authors such as Boxshall (2004) and Waloszek et al. (2005) argued from comparative morphology and well-preserved early arthropod fossils that a 'coxa' - the protopodite sensu Boxshall or basipod sensu Waloszek et al. - in the limbs behind the (a1) antennae/chelicerae was evidently a part of the euarthropod ground pattern. A coxa should, therefore, be present in all crown-group arthropods; mites included. In other words, in van der Hammen's (1977b) scheme arachnids would lack one of the key characters of Euarthropoda! Other potential synapomorphies of (Anactinotrichida + Palpigradi), or (Acari + Palpigradi) in general, have not been elaborated in the literature.

\section{Challenges to diphyly}

Partly as a result of some of the weakness outlined above, the diphyletic model has not been universally accepted, although various characters proposed in support of Acari turn out to have their own intrinsic problems. Thus, Acaromorpha sensu Dubinin $(1957,1959)$ was a monophyletic class restricted to mites and based on characters, such as the gnathosoma (regarded by some workers as homoplastic), poorly developed and reduced segmentation (a weak character), lack of a sternum (incorrect with respect to Anactinotrichida), a caudal body bend during development (at best only weakly expressed in Opilioacarida), female genitalia developed as a trilobite cone (in fact, absent in at least most Anactinotrichida; uncertain for Opilioacarida, see below) and six postembryonic instars (incorrect, cf. the prelarva) including hexapodal larvae (but see comments on Opilioacarida and Holothyrida above). Diphyly was also explicitly challenged by Sitnikova (1978), who recognized seven putative autapomorphies of Acari. These were: (1) a trend towards reducing the number of body segments (very weak), (2) the caudal body bend (see above), (3) reductive 'trends' in internal morphology (very weak), (4) 'similar' embryonic development (largely unknown), (5) hexapodal prelarva and larva (see above), (6) embryonization of the prelarva (also seen in other arachnids) and (7) trends towards shortening the life cycle (weak). As in Dubinin's scheme, some of these characters - segmentation, internal morphology, short life cycle - are potential apomorphies, but may also simply be associated with small body size. Others are weakly defined as noted above and commented upon by Lindquist (1984).

\section{Lindquist's support for Acari}

Lindquist (1984) offered the most detailed defence of mite monophyly, although subsequent authors tended to portray his rejection of diphyly in rather more robust terms than what he actually wrote. Lindquist questioned many of Zachvatkin's diagnostic characters for being plesiomorphies, scored incorrectly or based on unproven homologies. Eleven putative autapomorphies for a monophyletic Acari were elaborated by Lindquist (numbers in square brackets below correspond to his Table 8), and some of these have been further discussed by Alberti (2006). One of the strongest is a pair of infra/ subcapitular rutella (or corniculi) [1], which are modified, thickened setae with a distinctive toothed appearance in many groups which perhaps help masticate solid food. Lost (or not differentiated as such) to our knowledge in all prostigmatics (s. str.; see OConnor 1984), they are, nevertheless, observed in basal representatives of both acariform (Kethley 1982) and parasitiform mites (Johnston 1982; Figs 3, 5b and 6a). If rutella and corniculi really are homologous structures, then they occur in most anactinotrichid mites. Rutella are not known from other arachnids. Alberti (2006) noted, however, that the character was not well understood. Evans (1992) mentioned alternative morphological terms, and was cautious about assuming homology across different mite groups. Bernini (1986) suggested that they could be convergent, and if they were adapted for handling solid food then they might prove to be a putative apomorphy associated with a particular mode of life (see below). A weakly segmented idiosoma [6] (i.e. the rest of the mite body behind the gnathosoma) was also proposed as diagnostic for mites, and is reflected in an endless debate about the true number of 'opisthosomal' segments (Fig. 3). One should note that weak segmentation occurs in some other arachnids, like harvestmen or most spiders. A violet pigmentation in the idiosoma [7] is observed in the basal members of many mite groups and was tentatively regarded as an autapomorphy of Acari although its exact chemical composition remains unknown. It has not been reported in other arachnids, but Lindquist cautioned that it should be investigated in other soft bodied groups like harvestmen and palpigrades.

Some of Lindquist's (and other authors') support for Acari remains rather 'mite-specific'; i.e. hard to assess in, perhaps even inapplicable for, other arachnids. Consequently, these characters have been largely ignored by later authors investigating arachnid phylogeny. For example, five fundamental pairs of infra/subcapitular setae in the larva [3]. Most

(C) 2007 The Authors J Zool Syst Evol Res (2008) 46(1), 1-18 Journal compilation (C 2007 Blackwell Verlag, Berlin 
arachnids lack a sub- or infracapitulum (i.e. fused pedipalpal coxae) and data for setation patterns in the larva of non-mites is largely equivocal. Similarly, lyrifissures are usually called slit sensilla in spiders and other arachnids and three unique and reductive distribution patterns for mites were proposed: a maximum of three pairs on the sternum [4], and prodorsum [5] (i.e. the sclerite covering the proterosoma equivalent to the propeltidium of some other arachnids), and only one or two lyrifissures on the chelicerae [11]. Note that slit sense organs on the prodorsum may actually be lacking in actinotrichid mites (GA, personal observation). Identifying homologous elements in other arachnids would be helpful, especially those with a fully developed prosomal dorsal shield (or carapace) and/or where the sternum has become reduced, while Lindquist himself conceded that data on cheliceral lyrifissures (slit sensilla) in non-mite arachnids are incomplete. Similarly, the reduction of the number of setae to 2 or 3 on the second cheliceral article [10] has not been fully tested in other arachnids, and may to some extent be size-dependant. Large arachnids typically have more 'hairy' chelicerae, although some bdellid mites (of about $3 \mathrm{~mm}$ maximum size) secondarily have numerous cheliceral setae.

Other putative mite characters sensu Lindquist are less convincing. Lateral lips flanking the mouth ventrolaterally [2] appear to be present in Solifugae and Pseudoscorpiones too (van der Hammen 1989a; Dunlop 2000). Ingestion of solid food particles [8] occurs in Opiliones and the outgroup Xiphosura. Walter and Proctor (1998), in contrast to Lindquist (1984), made a strong case for particle-feeding being the plesiomorphic mode of life for mites as it occurs in numerous early derivative groups. That said, it should be noted that, for example, some ascid mites (Gamasida) can switch from predation with preoral digestion to fungus-sporefeeding in the absence of prey animals and thus food preferences can change in some groups under some circumstances (Evans 1992). Finally, a hexapodal prelarva [9] may not be unique to mites given that Lindquist (1984, p. 47) had to concede that for ricinuleids, which also have hexapodal (with rudimentary legs IV) instars, '...observations on a prelava are lacking.... Note that the opilioacarid prelarva the only anactinotrichid group where the prelarva is known differs form the prelarva of actinotrichid mites (Alberti 2006). In particular, opilioacarids clearly retain a large (but unsegmented) vestige of the fourth leg in the larva (Klompen 2000, figs 1 and 7) which raises questions about how exactly a hexapodal prelarva and/or larva in mites and ricinuleids should be scored and defined.

\section{A sister-group among the other arachnids?}

Despite the uncertainty over some of these characters supporting monophyly outlined above, most arachnologists who have investigated phylogeny have assumed that mites are monophyletic; one suspects, in part, because of their unfamiliarity with these animals in general. On this assumption, there are a number of alternative hypotheses in the literature (see also Walter and Proctor 1999). Some are fairly crude and typological, such as Petrunkevitch's grouping of Scorpiones, Pseudoscorpiones, the extinct Phalangiotarbida, Opiliones and Acari together in a subclass Latigastra Petrunkevitch, 1949, based on nothing more than a broad junction between the prosoma and opisthosoma. This division of the body may not even be applicable to actinotrichid mites.

(C) 2007 The Authors J Zool Syst Evol Res (2008) 46(1), 1-18 Journal compilation (C) 2007 Blackwell Verlag, Berlin

\section{Mites and whip scorpions}

Börner $(1902,1904)$ pointed out similarities between the fused pedipalpal coxae of mites - i.e. the infra/subcapitulum of their gnathosoma - and the fused pedipalpal coxae of Thelyphonida and Schizomida. This structure in the latter orders is sometimes referred to here (e.g. Petrunkevitch 1949) as the camerostome. Reuter (1909) again drew attention to these fused palpal coxae - see also the scoring of Shultz (1990, character 18) - and mentioned further similarities between mites and whip scorpions in embryological development and the loss of opisthosomal appendages. Reuter concluded that mites were probably derived either from Thelyphonida or Opiliones and, as noted above, excluded the opilioacarid mites from Acari sensu stricto under the (erroneous, see e.g. Shultz 1989; van der Hammen 1989a; Evans 1992) assumption that non-opilioacarid mites lack a patella (= genu in mite terminology). An overwhelming majority of the studies recover the lung-bearing whip scorpions as part of the clade most recently named Tetrapulmonata Shultz 1990: usually with a phylogeny of the form \{Araneae [Amblypygi (Thelyphonida + Schizomida)] $\}$. There seem little modern data to group the mites specifically with any of these tetrapulmonate arachnids and the fact that whip scorpions resolve in the more derived position, with spiders and whip spiders retaining unfused and (in spiders) mobile palpal coxae, strongly implies that coxal fusion in mites and whip scorpions is homoplastic. The character also occurs in Ricinulei (see below). A similarly shaped tritosternum occurs in anactinotrichid mites and whip spiders (Amblypygi).

\section{Holosomata and tracheal homologies}

Mites respire through tracheae, with the exception of almost all astigmatic mites; indeed Kramer (1877) divided mites into Tracheata and Atracheata groups based on this character. As their name implies, astigmatic mites lack an internal respiratory system, although genital tracheae have been reported in the astigmatic Gohieria (van der Hammen 1989a). Due to the general presence of tracheae, mites have usually been resolved near one or more of the other tracheae-bearing arachnid orders. The fact that different mites have their tracheal openings in different places - reflected in names like Pro-, Hetero- or Mesostigmata - raises serious questions about the homology of tracheae across all mites (and indeed all arachnids). As Alberti (2006) noted, none of the various spiracular openings seen in Actinotrichida are topologically equivalent to either the four dorsal spiracles in Opilioacarida or the one lateral pair of opisthosomal spiracles in Parasitiformes. Despite such criticisms of non-homologous tracheal positions, a crude and simplistic division of the arachnids based on their respiratory organs remains popular. It goes back at least to Lankester (1881) who broadly divided them into Aerobranchia, characterized by book-lungs, and Lipobranchia, with tracheae. The latter group thus included Solifugae, Pseudoscorpiones, Opiliones and Acari; although at least the mites were implicitly derived from spiders in Lankester's geneological tree. Ricinuleids were excluded as there was still at that time confusion about their ordinal status. In a broader sense, the inclusion of mites into a tracheate (or lungless) group is also reflected in more recent studies; most significantly as the clade Apulmonata Firstman, 1973 - which was adopted by Weygoldt and Paulus (1979) as one of the major divisions in their seminal study of arachnid relationships. 
Pocock (1893) effectively retained Lankester's tracheate group of arachnids as an unnamed taxon, but removed Solifugae into its own subclass (Mycetophora Pocock, 1893) to leave a further subclass Holosomata Pocock, 1893 comprising Pseudoscorpiones, Opiliones and Acari. Holosomata was defined mostly on non-solifuge characters, i.e. an undivided carapace and the absence of solifuge autapomorphies. Other diagnostic characters were scored incorrectly. Holosomatid arachnids sensu Pocock should lack prosomal tracheae, but they are present (indeed define) prostigmatic mites. Holosomata should also lack divided trochanters, but a double femur (essentially the same character state) is present in, for example, opilioacarid mites (e.g. Shultz 1989; van der Hammen 1989a). Despite this rather unconvincing and negative suite of characters, Börner (1902) accepted Pocock's Holosomata group with Solifugae as their sister taxon.

\section{Mites and harvestmen}

Pocock (1893, pp. 7-8) actually went beyond Holosomata in his discussion and stated that Acari was most closely related to, and indeed probably descended from, Opiliones. Central to this hypothesis are similarities between cyphophthalmid harvestmen and opilioacarid mites (Fig. 1), at least in superficial appearance. For example, Börner (1904) redefined his earlier Cryptoperculata Börner, 1902 clade as arachnids with a poorly developed genital operculum and (generally) an anteriorly displaced gonopore (but see below). Cryptoperculata had a phylogeny of the form $\langle$ Ricinulei \{Trigonotarbida [Opiliones (Opilioacarida + other Acari)] $\}\rangle$ and for Börner (1904) opilioacarids thus bridged the 'morphological gap' between harvestmen and the remaining mites. Recall that other authors (e.g. Reuter 1909) did not regard opilioacarids as bona fide mites. Some authors (Michael 1901; Carpenter 1903) also hinted that mites were derived arachnids, probably related to harvestmen, but did not go into detail. Dahl (1911) grouped harvestmen and mites together on the character of no (or hardly any - see also Alberti 2006) trichobothria; however, these sensory hairs are missing in a number of arachnids and their distribution across different orders seems to be of limited phylogenetic value (cf. Shultz 1990, character 48).

Woolley (1961) concluded that the similar, chelate chelicerae with three articles implied that mites originated from opilionid-like ancestors. Uchida (1966) proposed that Acari is the most 'modern' arachnid order and that they show several (unspecified) similarities with Opiliones. Savory (1971) placed harvestmen, mites and the extinct Phalangiotarbida together, mentioning the 'obvious' (but again unspecified) resemblances between opilioacariforms and cyphophthalmids. Yoshikura (1975) regarded Acari as the most 'highly specialized' arachnids and grouped mites, harvestmen, solifuges and ricinuleids together based on the putative characters of tracheae and eggdeposition on the substrate. Yoshikura further grouped Acari and Opiliones together as an explicit clade: Opilionides Yoshikura, 1975. We could find no earlier mention of this supraordinal name and presume it was first proposed as a higher taxon here. Unique synapomorphies were not elaborated in Yoshikura's discussion, but from the character descriptions this appears to be based primarily on the presence of both a penis and an ovipositor in harvestmen and at least some Acari.
Kraus (1976) also noted the presence of both a penis and a genital opening shifted forwards up between the leg coxae as potential synapomorphies of mites and harvestmen. This latter character is unconvincing. While applicable to male gamasid mites, other mites have a gonopore opening behind the last pair of leg coxae (the usual position for arachnids) and not in an especially anterior position, i.e. thrust forward and nestled between the leg coxae as in, for example, harvestmen. It is a good example of an over-generalization being translated into a potential synapomorphy of Acari and other groups of arachnids. Grasshoff (1978) took a construction morphology approach - identifying grades of organization rather than clades - and derived Acari from the same basal evolutionary grade as Opiliones. Klausnitzer and Richter (1981) identified the genital opening, the form of the midgut diverticula and the construction of the penis as support for (Acari + Opiliones) and Shear (1982) summarized the conventional wisdom of the time with the claim that 'opilionids are evidently closest to some groups of mites'.

Given the potential significance of these genital characters, it is worth recapitulating the actual distribution of the penis and ovipositor among the mites. A penis has never been recorded from Anactinotrichida. In Actinotrichida some (more derivative prostigmatic) groups, such as tetranychoids, raphignathoids, cheyletoids, the heterostigmatic superfamilies and all astigmatics (see e.g. Evans 1992; Alberti and Coons 1999; Walter and Proctor 1999), have a penis in the form of a sclerotized organ specifically used in copulation. In a few less derivative prostigmatic groups, e.g. Tydeoidea and Cunaxidae, the presence of a penis is found as an ingroup feature (E. Lindquist, personal communication). Oribatids, and those prostigmatics which practise indirect sperm transfer, can also have a 'penis' or 'ejaculatory complex' - but here it is used to shape and deposit a spermataphore, and not for copulation. Hence, the term 'spermatopositor' would be more appropriate (van der Hammen 1980; Alberti and Coons 1999). It seems likely that this spermatopositor has been transformed into a functional penis for copulation several times independently in Actinotrichida. Furthermore, spermatophores have recently been reported from cyphophthalmid harvestmen (Karaman 2005; Novak 2005; Schwendinger and Giribet 2005). However, the actual mode of sperm transfer remains not known; more derived harvestmen evidently copulate. Taken together, this undermines a penis sensu stricto and its use in copulation as explicit support for (Acari + Opiliones) and reiterates the danger of trying to score characters for a 'typical' mite based on a composite of the two major lineages. Following Alberti (2006, Table 2), female Opilioacarida and Ixodida have a simple ovipositor with two lobes - although Vázquez and Klompen (2002, p. 309) noted that the ovipositor seemed to be trilobed in at least their American material - while Gamasida (?apomorphically) lack this structure altogether. Many Actinotrichida have a more complex, telescoping, distally trilobed ovipositor (see also Evans 1992; Alberti and Coons 1999 for details). Thus at best an ovipositor of sorts seems to be present in the ground pattern of both major lineages and may offer some weak support for (Acari + Opiliones).

However, based on several morphological and molecular studies, a sister taxon for Opiliones distant from Acari seems to be better supported. Thus, Shultz (1990) proposed a taxon Dromopoda \{Opiliones [Scorpiones (Pseudoscorpiones + Solifugae)]\} which was also recovered by Wheeler and Hayashi (1998). Modifying his concept, Shultz (2000) suggested an

(C) 2007 The Authors J Zool Syst Evol Res (2008) 46(1), 1-18 Journal compilation (C) 2007 Blackwell Verlag, Berlin 
explicit sister-group relationship of Scorpiones and Opiliones based on a detailed analysis of harvestman skeletomuscular anatomy. The extensive analysis of Giribet et al. (2002) also supported a monophylum Dromopoda.

\section{Mites and camel spiders}

The Rev. Octavius Pickard-Cambridge proposed a new order of mite-like arachnids, Poecilophysidea Cambridge, 1876, based on material from the isolated island of Kerguelen. These specimens were evidently prostigmatic rhagidiid mites (see Dunlop 1999 for a review), but it is clear that Cambridge was strongly influenced by similarities between these animals and the much larger Solifugae (Fig. 1). Banks (1915, pp. 21-22) even went so far as to suggest that 'It is probable that [Rhagidia] is the most primitive of all existing mites and points to a close relationship of the Acarina to the Solpugida'. While rhagidiid mites are no longer generally considered a basal group, Grandjean (1936b, 1954) also pointed out similarities between camel spiders and the palaeoacariform mites in particular, namely the proterosoma/propeltidium region with four pairs of appendages and the mouthparts with the mouth borne on a projecting 'rostrum'. The latter character was re-investigated by Dunlop (2000), who noted the excessive number of names proposed in the literature for what appear to be homologous structures, before suggesting that a prominent, forward-projecting epistomo-labral (terminology after Snodgrass 1948) plate flanked by a pair of lateral lips is a potential synapomorphy of mites, camel spiders and pseudoscorpions; see also Bernard (1897) for essentially the same hypothesis.

Grandjean noted a further potential homology between the Claparède organs of actinotrichid mites and the 'flügelförmigen Organe' in early instars of camel spiders. The latter character is probably equivalent to the 'lateral organ' observed in early instars of whip spiders (Amblypygi) and whip scorpions (Thelyphonida). A metamerically similar feature was discussed for opilioacarid mites (Lindquist 1984). But this may be a misinterpretation of the so-called sternal verrucae which in fact are structurally much different from the genital verrucae present in these mites (GA, personal observation). In any case the consensus is, based also on ultrastructural studies of whip spiders and actinotrichid mites, that the Claparède organ and its likely homologues are vestigial (i.e. plesiomorphic) retentions of the exopod (or epipod in alternative terminologies) on the second walking leg (Zissler and Weygoldt 1975; Alberti 1979; Telford and Thomas 1999). A number of authors (e.g. Wagner 1895; Carpenter 1903) drew attention to the fact that only camel spiders and, at least the prostigmatic, mites have tracheae opening through spiracles in the prosoma. Others (e.g. Reuter 1909) regarded this as a homoplastic development and again this touches on the general question of whether the position of tracheal spiracles offers useful support for alternative phylogenetic relationships.

Wagner (1895) regarded mites as 'degenerate' arachnids (i.e. having many reductive characters), but tentatively grouped them with Solifugae and Pseudoscorpiones. A further character apparently shared by all these three orders, but widely overlooked in the literature, is the fact that the movable finger of the chelate chelicera articulates ventrally against the fixed finger (Figs 4a and 6c). In other arachnids (e.g. scorpions) the free finger is more or less dorso-lateral and this same basic orientation is retained in spiders which have transformed the dorsal free finger into the fang. That said, this is not a completely clear-cut character and harvestmen, for example, have a more laterally positioned free finger. It should be added that although many authors have accepted solifuges and pseudoscorpions as sister-taxa (e.g. Börner 1904; Weygoldt and Paulus 1979; van der Hammen 1989a; Shultz 1990) - a rare point of consensus among these phylogenies - this relationship has recently been challenged by Alberti and Peretti (2002) based on sperm and male genital morphology. These authors found more similarities in genital characters (specifically testis structure, the tendency to form sperm aggregates and ultrastructure of sperm cells) between actinotrichid mites and solifuges (see also Alberti 2000 and references therein) and speculated again about the possibility that Acari is not monophyletic.

\section{Acaromorpha}

In a similar vein to van der Hammen's Cryptognomae concept (see above), a number of authors have argued that ricinuleids (Fig. 1) are the sister-group of all mites, to the point that this has become the almost accepted wisdom. In the first major cladistic study of arachnids, Weygoldt and Paulus (1979) recognized (Acari + Ricinulei) - here referred to as Acarinomorpha Weygoldt and Paulus, 1979 - based solely on the character of hexapodal larva. Harvestmen were placed as their outgroup. Lindquist (1984) expanded this, proposing four characters supporting (Acari + Ricinulei): (1) hexapodal larvae, (2) a movable gnathosoma, (3) a scaly or denticulate labrum and (4) divided trochanters in legs 3 and 4. Shultz (1990) also recovered (Acari + Ricinulei) with hexapodal larva and a 'subcapitulum' (i.e. separation of the palpal coxae from the rest of the body via a distinct articulation) as unequivocal synapomorphies; the latter convergent with whip scorpions. Lindquist's scaly labrum character was rejected as speculative, while the double 'trochanter' was interpreted as symplesiomorphic based on an earlier (Shultz 1989) survey of limb morphology. Shultz referred to (Acari + Ricinulei) as Acaromorpha, although as noted above this name was originally proposed exclusively for mites by Dubinin (1957). Acaromorpha was also recovered by Wheeler and Hayashi (1998), largely based on Shultz's characters and supplemented by molecular data.

\section{The challenge to Acaromorpha}

Ricinuleids have two further unusual characters. First, the opisthosoma has tergites separated into median and lateral plates; transformed into a medially divided scutum in some fossil genera (see Selden 1992). Secondly, there is the curious 'locking' mechanism in which the first opisthosomal tergite forms a ridge which slots under the posterior margin of the carapace, with corresponding ventral indentations at the front of the opisthosoma to accommodate the trochanters of the posteriormost (fourth) pair of legs. These modifications help 'lock' the two halves (tagmata) of the body together, but the functional significance of this system remains uncertain. Both these features (divided tergites, a locking ridge with dorsal and ventral components) are also characteristic of the extinct Trigonotarbida; a group now known in considerable anatomical detail thanks to some exceptionally preserved fossils (e.g. Shear et al. 1987; Fayers et al. 2005 and references therein). Earlier, Karsch (1892) went so far as to regard ricinuleids as the only living descendants of trigonotarbids; using the now 
defunct name Meridogastra, Thorell in Thorell and Lindström, 1885 for the latter. Trigonotarbids were subsequently allied to-or confused with-harvestmen and were even artificially divided into two unrelated orders by Petrunkevitch (1949). The position of trigonotarbids was clarified by the discovery of two unequivocal pairs of book-lungs (Claridge and Lyon 1961), clearly characteristic for Tetrapulmonata sensu Shultz (1990) (= Megoperculata sensu Weygoldt and Paulus 1979). Shear et al. (1987) and Selden et al. (1991) identified numerous additional characters in the mouthparts and limbs which convincingly resolve trigonotarbids as basal tetrapulmonates, i.e. a relationship of the form 〈Trigonotarbida \{Araneae [Amblypygi (Thelyphonida + Schizomida)] $\}$.

What does this have to do with mites? Shear et al. (1987) acknowledged that both trigonotarbids and ricinuleids had a locking ridge, but regarded the character as 'obviously convergent'. Dunlop (1996) reinvestigated this and suggested that the evident similarities in opisthosomal morphology (especially the divided tergites and locking mechanism) should be treated as potentially homologous, and thus could be proposed as synapomorphies of (Ricinulei + Trigonotarbida). He further noted that the two-articled, subchelate ricinuleid chelicerae with a dorsally articulating 'fang' are more like those of tetrapulmonate arachnids than those in (at least anactinotrichid) mites, with three articles (Fig. 5a) the most distal of which articulates ventrally (see above). Together, these characters potentially outweigh the hexapodal larva supporting Acaromorpha (see above) and indeed the comprehensive analysis of Giribet et al. (2002) also recovered (Ricinulei + Trigonotarbida) basal to the remaining tetrapulmonate arachnids. A further potential synapomorphy in the form of a tiny chela at the tip of the pedipalp has also recently been identified in both ricinuleids and trigonotarbids (J.A. Dunlop, C. Kamenz and G. Talarico, unpublished data). However, Lindquist (1984) suggested that the tiny chelate digits of the palpotarsal apotele of ricinuleids might be homologous and derived from a more plesiomorphic clawed condition similar to that retained in opilioacarids. Yet, essentially, trigonotarbids may drag the ricinuleids into the tetrapulmonate clade, even though ricinuleids have tracheae, rather than the book-lungs. If this model is correct, then the hexapodal larva and (perhaps) the gnathosoma would have to be treated as homoplastic characters for mites and ricinuleids.

\section{Molecular data}

Molecular data have begun to be used for resolving relationships within particular groups of mites; see e.g. Cruickshank (2002), Lekveishvili and Klompen (2004), Maraun et al. (2004), Murrell et al. (2005), Klompen et al. (2007) and references therein. However, molecular methods directed specifically at resolving the relationships of mites with respect to other arachnids are still in their infancy and only a handful of taxa have been sampled and compared thus far. Wheeler and Hayashi (1998: fig. 6) recovered a clade based on 18S and 28S rDNA essentially of the form \{Xiphosura [Opiliones (in part) (Anactinotrichida + Pycnogonida) $]\}$. No actinotrichid mites were tested. Giribet et al. (2002: fig. 7) used the same molecules to resolve a tree essentially of the form: Pycnogonida \{Actinotrichida [Xiphosura (Ricinulei + other arachnids)] $\}$, whereby the tested Anactinotrichida resolved as the sister group of Pseudoscorpiones. These results, while partly discordant, have the potential to draw the monophyly of the mites (and even the arachnids) into question. Most recently, the molecular data of Klompen et al. (2007) did recover a monophyletic Acari, albeit with only moderate support compared to their strong support for the two major mite lineages and various ingroup anactinotrichid clades which were the focus of this study. Further efforts should be made to include molecular data sampled widely from both lineages to reflect their inherent diversity and test the results against wellestablished ingroups defined by other criteria (e.g. Gamasida, Parasitengona, Heterostigmata).

\section{Morphological questions 1: tagmosis}

Two characters seem to be of particular interest for understanding the early origins and affinities of mites: tagmosis and the gnathosoma. To reiterate, in the ground pattern of Actinotrichida the principal division of the body lies between the second and third pair of walking legs (Fig. 4b) and thus defines an anterior proterosoma bearing four pairs of limbs (chelicerae, palps and two pairs of walking legs). To this extent they lack the traditional arachnid prosomal dorsal shield (or carapace), an observation reflected in the coding of, say, Shultz (1990, character 1). As Alberti (2006) noted, there has been considerable debate about whether this represents a plesiomorphic (e.g. Carpenter 1903; Dubinin 1957, 1959; Kraus 1976) or derived condition - a debate going back at least to Dugès (1834). Modern applications of Hox gene data (summarized by Scholtz 2001), which homologized the chelicerate chelicerae with the mandibulate antennae, combined with new palaeontological interpretations tend now to support the idea that actinotrichid mites do retain a rather plesiomorphic construction of the body: namely the four-limbed 'euarthropod head'. This concept has been elaborated by Walossek and Müller (1998) and is seen in a wide range of Cambrian fossil arthropods, with the caveat that some early arthropods express alternative patterns of head limb morphology. A fundamental role for four limb-bearing anterior segments is supported by expression patterns of the engrailed gene (Scholtz 1998) in recent arthropods, and Waloszek et al. (2005: fig. 5) regarded this four-limbed head as one of the key defining characters of Euarthropoda.

Among potential euchelicerate outgroups, this 'head' seems to be present in Pycnogonida (Vilpoux and Waloszek 2003; Dunlop and Arango 2005, and references therein). We should note that a rather different interpretation of sea spider head segmentation was recently proposed by Maxmen et al. (2005), but see Jager et al. (2006) for a response based on Hox gene data which supports the more traditional model. Chen et al. (2004) also recognized a series of 'great-appendage' or 'megacherian' fossil arthropods as potential members of the euchelicerate stem-line. These have (like actinotrichids) a head with four pairs of limbs, the first of which is raptorial to subchelate, and could conceivably be a forerunner of the chelicerae (reviewed by Dunlop 2006). One could argue that at least Actinotrichida retain the euarthropod head as a fundamental division of their body - which would be inconsistent with a highly derived position among the arachnids as postulated by some authors. This 'retained head' might be true of groups like Solifugae and Palpigradi too, which also have a region with four limbs covered by the propeltidium of the carapace. While previous cladistic analyses have invariably scored this divided carapace as a derived character state, this ignores, for example, Kaestner's (1952) study of solifuge development where he explicitly argued that the division of the carapace in Solifugae is not secondary.

(C) 2007 The Authors J Zool Syst Evol Res (2008) 46(1), 1-18 Journal compilation @ 2007 Blackwell Verlag, Berlin 
To take this further, one could even argue that groups like actinotrichid mites, solifuges and palpigrades lack a prosoma per se, although this depends on whether the prosoma is defined in terms of the (dorsal) head shield or the (ventral) distribution of walking legs. There remains, of course, the Anactinotrichida which seem to have, at least in Opilioacarida, the more traditional prosoma-opisthosoma tagmosis, although Klompen (2000) was more circumspect and preferred to refer simply to an 'anterior' and 'posterior' area of the body. Further comparative work on defining tagma boundaries across all mites would be helpful.

\section{Morphological questions 2: the gnathosoma}

The gnathosoma (Figs 5c and 6a) - the capitulum or capitellum in some (misleading) terminologies - is another key character for resolving the affinities of mites, yet there remain questions about its interpretation and distribution. Some authors regarded it as the most convincing synapomorphy of (Anactinotrichida + Actinotrichida) (Weygoldt and Paulus 1979), others use it to support (Acari + Ricinulei) (Lindquist 1984) while others regard it as homoplastic (Van der Hammen 1989a). The gnathosoma has a number of constituent parts and, for example, Shultz (1990) scored Acari, Ricinulei, Thelyphonida and Schizomida as having fused pedipalpal coxae (e.g. Fig. 5c) (not a gnathosoma sensu stricto), but used the articulation between these coxae and the rest of the body as explicit support for (Acari + Ricinulei). Van der Hammen (1980) defined the gnathosoma as a secondarily movable pseudotagma, specifically: 'Division of the body anteriorly of the circumcapitular furrow, bearing two pairs of appendages...' He recognized two gnathosomal components: the cheliceral frame and the infracapitulum (= subcapitulum). The cheliceral frame is effectively the, often membranous, attachment area of the chelicerae, while the infracapitulum includes the fused palpal coxae, pedipalps, labrum and lateral lips as well as the mouth opening and the pharynx.

In his detailed comparative study of arachnid mouthparts Snodgrass (1948) proposed that the one unique feature of the mite gnathosoma was a sclerotization of the wall above the chelicerae to form the tectum; a structure which is fused laterally with the pedipalpal coxae to effectively form a ring into which the chelicerae fit (see especially Snodgrass 1948, fig. 22A). Although this region is in fact sclerotized only in Ixodida and Gamasida, it is present in all Acari as a more or less distinct region composing the dorsal and lateral parts of the so-called cheliceral frame and was termed the tegulum (Grandjean 1957; van der Hammen 1980, 1989a; Alberti and Coons 1999). In support of his diphyletic model van der Hammen challenged the homology of the gnathosoma. Acknowledging a similar overall shape, his principle differences related to the musculature and to the way in which the infracapitulum connects to a channel system coming from the coxal glands (see also Alberti and Coons 1999; Alberti 2006). In Actinotrichida the muscles moving the gnathosoma were cited as inserting on the so-called capitular apodeme, i.e. an internal projection of the gnathosoma just below the chelicerae. By contrast the gnathosoma in Anactinotrichida (and perhaps also ricinuleids) was cited as being moved by muscles inserting in a deeper position at the base of the gnathosoma (Fig. 3). Now, whether these differences in channel systems and muscle insertion position (and other features sensu Alberti 2006) are sufficient to invalidate the homology of the gnathosoma

(C) 2007 The Authors J Zool Syst Evol Res (2008) 46(1), 1-18 Journal compilation (C) 2007 Blackwell Verlag, Berlin remains a moot point - these could just represent alternative autapomorphies respectively defining the two main lineages but this is a character complex which would certainly merit further investigation. A major goal must also be to establish whether Ricinulei have a gnathosoma sensu stricto, or whether they simply retain movable pedipalpal coxae (a plesiomorphy) which have independently fused together; something which has also occurred in Thelyphonida and Schizomida.

\section{Morphological questions 3: scoring further characters}

As noted above, several characters which are well-known and frequently considered in ingroup discussions on Acari are not easily applicable to other arachnid groups. For example, tarsal receptor organs on the palps and legs could provide further information. With respect to tarsal pore organs on legs I, these have only be found in Anactinotrichida (Opilioacarida, Holothyrida and Ixodida; Haller's organ), but not in Actinotrichida. They are also present in spiders (Moritz 1993). In Ricinulei, such organs are represented by deep invaginations occurring on the tarsi of legs I and II (Talarico et al. 2005). While clusters of sensory sensilla at the distal ends of the first legs (frequently used as feelers) may have arisen convergently, it is clear that Anactinotrichida and Actinotrichida have solved the problem in different ways. More details are needed regarding sensory structures in, for example, the preoral cavity or in the chelicerae, also taking non-acarine arachnids into consideration (e.g. Alberti and Coons 1999; De Lillo et al. 2005; G. Talarico, J. G. Palacios-Vargas and G. Alberti unpublished data). Another possibility for further studies may be the fine structures of the eyes. The evident apomorphic lack of median eyes in Anactinotrichida is a remarkable difference compared with Actinotrichida. Are there differences with respect to the lateral eyes too? Kaiser and Alberti (1991) described the fine structure of the lateral eyes of Neocarus texanus (Opilioacarida) as being rather complex and strikingly different from actinotrichid eyes known at that time (see also Alberti and Coons 1999). None of the early derivative actinotrichid mites has yet been investigated preventing further comparisons. We also have to concede that a character which was much emphasized by van der Hammen (1989a) - and frequently referred to in the present review namely the different insertion points of the gnathosomal retractor muscles, has been studied only in a limited number of rather derived species. It is necessary to widen our knowledge of these important skeleto-muscular features in basal representatives of all major mite lineages. A further promising line of investigation has already been initiated by Rockett and Woodring (1972) revealing pronounced differences with respect to, for example, leg formation or pre-ecdysial inactivity (see also Evans 1992) and by Norton and Kethley (1994) on patterns of ecdysis. Again, we stress that more data are needed particularly for early derivative mite taxa and other arachnid groups.

\section{Conclusions}

Supporters of a diphyletic origin of mites have (Zachvatkin 1952; van der Hammen 1989a) largely failed to identify convincing and unequivocal synapomorphies linking different mite taxa to two (or more) different sister-groups among the remaining arachnids (cf. Weygoldt 1998). The fact that Anactinotrichida and Actinotrichida may have separated a long time ago and have since developed fundamentally 
Table 1. Potential explicit synapomorphies derived from the literature linking one (or both) lineages of mites to other arachnid orders. Some of these characters are still controversial in their interpretation, while features regarded in this paper as probably being plesiomorphic and/or as unreliable (cf. Epimerata) have not been included; see text for details. Future comparative work can hopefully expand this still surprisingly small dataset

\begin{tabular}{|c|c|c|}
\hline & Anactinotrichida & Actinotrichida \\
\hline Opiliones & Ovipositor? & Ovipositor? \\
\hline \multirow[t]{4}{*}{ Solifugae } & Projecting epistomal plate + lateral lips & Projecting epistomal plate + lateral lips \\
\hline & Free finger of chelicera articulates ventrally & Free finger of chelicera articulates ventrally \\
\hline & & Simple, aflagellate sperm \\
\hline & & Large glandular area of the testis producing secretions \\
\hline \multirow[t]{2}{*}{ Pseudoscorpiones } & Projecting epistomal plate + lateral lips & Projecting epistomal plate + lateral lips \\
\hline & Free finger of chelicera articulates ventrally & Free finger of chelicera articulates ventrally \\
\hline \multirow[t]{2}{*}{ Ricinulei } & Hexapodal larva & Hexapodal larva \\
\hline & $\begin{array}{l}\text { Gnathosoma (sensu Lindquist) } \\
\text { or gnathosoma with basal muscle insertion } \\
\text { (sensu van der Hammen) }\end{array}$ & Gnathosoma (sensu Lindquist) \\
\hline Thelyphonida/Schizomida & Fused pedipalpal coxae & Fused pedipalpal coxae \\
\hline Amblypygi & Slender tritosternum & \\
\hline
\end{tabular}

different morphologies (cf. Grandjean 1936a, 1970) is unhelpful. Even if the gnathosoma can be shown to be homoplastic, it does not exclude the possibility that anactinotrichid and actinotrichid mites are still sister-groups, however remote their common ancestry might be. As explicit evidence for diphyletic origins (Table 1), a specific pattern of gnathosoma musculature may support (Anactinotrichida + Ricinulei), while sperm and testis morphology favours (Actinotrichida + Solifugae). The proterosoma-hysterosoma tagmosis (Fig. 4b) should also be mentioned as something which differentiates at least the Actinotrichida from all other Euchelicerata, although this proterosoma itself may be a plesiomorphic retention of the original euarthropod head. In general, authors favouring diphyly should be encouraged to root their character polarities within the rest of the Arachnida.

Overall, a monophyletic Acari seems the most favoured hypothesis at present, but different authors have used different data to support it, as evidenced by the alternative ways of interpreting the gnathosoma listed above. If homologous across different groups, then rutella in the mouthparts (Figs $5 \mathrm{~b}$ and 6a) would be another unique feature restricted to Acari; but secondarily lost in some groups. Other potential autapomorphies proposed in the literature are either vaguely defined, difficult to score for the remaining arachnids, present in other arachnids or probably represent plesiomorphies. Alternative models for the sister group of all Acari, and the apomorphic characters in their favour, are summarized in Table 1. A final resolution can only come as a part of a wider cladistic analysis, in this context, we can only reiterate the need to break down traditional barriers between acarology and arachnology and encourage further detailed comparative morphological studies, such as Alberti and Storch (1983), Shultz (1989), Ludwig and Alberti (1990), Alberti (2000) and Alberti and Peretti (2002), including mites and other arachnids. We should also acknowledge a debt to van der Hammen. Even if in the long run his hypotheses prove to be incorrect, he is still the only author in recent years to systematically attempt to integrate the mites into broader studies of chelicerate morphology and evolution.

\section{Acknowledgements}

We thank Giovanni Talarico for advice on Ricinulei and Peter Michalik (Greifswald) for technical assistance. We also wish to express our particular gratitude to Evert E. Lindquist, Gonzalo Giribet and two further reviewers for their stimulating and constructive comments on an earlier version of this paper.

\section{Zusammenfassung}

Die Verwandschaftsbeziehungen der Milben und Zecken: Ein Überblick

Spinnentiere, die man konventionell als Milben und Zecken anspricht, können in zwei gut definierte, 'clades' untergliedert werden, nämlich Anactinotrichida und Actinotrichida. Für diese Gruppen wurden in den letzten Jahren bzw. Jahrzehnten jeweils eine ganze Reihe möglicher Autapomorphien bzw. reziproker Unterschiede zusammengetragen. Die Frage, ob beide Gruppen in einem Schwestergruppenverhältnis zueinander stehen und somit ein Monphylum Acari bilden, wird allerdings unterschiedlich beantwortet. Ältere Autoren, die beide Gruppen als von einander unabhängig entstanden interpretierten, konnten keine allgemein überzeugenden Synapomorphien zwischen einer dieser Linien und anderen Arachnidengruppen aufzeigen, obwohl neuere Arbeiten zur Reproduktionsbiologie einige sehr detaillierte Ergebnisse zu diesem Bereich geliefert haben. Darüber hinaus hat sich gezeigt, daß Merkmale, die zur Begründung einer Monophylie der Acari aufgeführt wurden, einer genaueren Analyse nicht wirklich standhalten, wenn die Gesamtheit der Arachnida in Betracht gezogen wird. Ein weiteres Problem für einen effektiven morphologischen Vergleich zwischen Acari und anderen Arachnida ergab sich einerseits auch dadurch, daß sich für beide Gruppierungen eine differierende Nomenklatur entwickelt hat, und andererseits fundamentale Acarispezifische Merkmale nur schwer oder gar nicht bei anderen Arachniden zu erkennen sind. Fehlschlüsse ergaben sich auch dadurch, daß taxon - spezifische Merkmale, die für eine der Gruppen Gültigkeit haben, als generell für Acari typisch gehandelt wurden. In der vorliegenden Arbeit werden frühere Hypothesen über die Verwandtschaft der Acari vorgestellt. So wurde diskutiert, ob Acari basale Spinnentiere seien oder eher stark abgeleitete. Abgesehen von einigen wenig fundierten frühen Hypothesen wurden die Acari - als Gesamtheit oder als Teilgruppen - interpretiert als: Schwestergruppe aller anderen Arachnida (basierend auf der Tagmosis), eng verwandt mit den Opiliones (im wesentlichen durch die Genitalmorphologie begründet), mit den Palpigradi (basierend auf einer umstrittenenen Interpretation der Extremitätenmorphologie), mit den Solifugen (mit Unterstützung durch Besonderheiten der Mundregion und neuerdings möglicherweise der Reproduktionsorgane) und den Ricinulei (basierend auf dem Vorkommen einer sechs-beinigen Larve und vielleicht auch Übereinstimmungen im Mundbereich). Wir können hier keine definitive Lösung der Frage nach der Stellung der Acari innerhalb der Arachnida liefern, sondern möchten einerseits einige bedeutende Merkmale hervorheben, von denen wir meinen, dass sie in zukünftige phylogenetische Analysen verstärkt eingehen sollten. Andererseits soll auf vielversprechende Felder für zukünftige Untersuchungen verwiesen

(C) 2007 The Authors J Zool Syst Evol Res (2008) 46(1), 1-18 Journal compilation (C) 2007 Blackwell Verlag, Berlin 
werden. Hierbei erscheinen uns eine vertiefte Erforschung der Tagmosis sowie der Natur des Gnathosomas von größter Bedeutung.

\section{References}

Abendroth ER (1868) Ueber Morphologie und Verwandschaftsverhältnisse der Arachniden. Inaugral-Dissertation, Universität Leipzig. Oswald Kollmann, Leipzig.

Alberti G (1975) Prälarven und Phylogenie der Schnabelmilben (Bdellidae, Trombidiformes). Z f zool System Evolut-forsch 13:44 62.

Alberti G (1979) Fine structure and probable function of genital papillae and Claparède organs of Actinotrichida. In: Rodriguez JG (ed.), Recent Advances in Acarology. II. Vth International Congress of Acarology, East Lansing. Academic Press, New York, pp 501507.

Alberti G (1980a) Zur Feinstruktur der Spermien und Spermiocytogenese der Milben(Acari) I. Anactinotrichida Zool Jb, Anat 104:77138.

Alberti, G (1980b) Zur Feinstruktur der Spermien und Spermiocytogenese der Milben(Acari) II. Actinotrichida Zool Jb, Anat 104:144 203.

Alberti G (1991) Spermatology in the Acari: systematic and functional implications. In: Schuster R, Murphey PW (eds), The AcariReproduction, Development and Life History Strategies. Chapman \& Hall, London, pp 77-105.

Alberti G (2000) Chelicerata. In: Jamieson BGM (ed.), Progress in Male Gamete Ultrastructure. In: Adiyodi KG, Adiyodi RG (eds), Reproductive Biology of the Invertebrates. Vol. 9B. Oxford \& IBH Publishing, Wiley, New Delhi \& New York, pp 311-388.

Alberti G (2006) On some fundamental characteristics in acarine morphology. Atti della Accademia Nazionale Italiana di Entomologia. Rendiconti LIII-2005:315-360.

Alberti G, Coons LB (1999) Acari-Mites. In: Harrison FW (ed.), Microscopic Anatomy of Invertebrates, Vol. 8c. John Wiley \& Sons, Inc., New York, pp 515-1265.

Alberti G, Michalik P (2004) Feinstrukturelle Aspekte der Fortpflanzungssysteme von Spinnentieren (Arachnida). Denisia NS 14:1-62.

Alberti G, Peretti AV (2002) Fine structure of male genital system and sperm in Solifugae does not support a sister-group relationship with Pseudoscorpiones (Arachnida). J Arachnol 30:268-274.

Alberti G, Storch V (1983) Zur Ultrastruktur der Mitteldarmdrüsen von Spinnentieren (Scorpiones, Araneae, Acari) unter verschiedenen Ernährungsbedingungen. Zool Anz 211:145-160.

Alberti G, Kaiser T, Klauer AK (1996) New ultrastructural observations on coxal glands (nephridia) of Acari. In: Mitchell R, Horn DJ, Needham GR, Welbourn WC (eds), Acarology IX, Proceedings. The Ohio Biology Survey, Columbus, pp 309-318.

Alberti G, Seniczak A, Seniczak S (2003) The digestive system and fat body of an early-derivative oribatid mite, Archegozetes longisetosus Aoki (Acari: Oribatida, Thrypochthoniidae). Acarologia 43:149219.

André M, Lamy E( 1937) Les Idées Actuelles sur la Phylogénie des Acariens. Published by the Authors, Paris.

Banks N (1915) The Acarina or mites. A review of the group for the use of economic entomologists. Rep US Dept Agric 108: $1-142$

Bernard HM (1892) Some observations on the relation of the Acaridae to the Arachnida. J Linn Soc, Zool 24:279-291.

Bernard HM (1897) "Wind scorpions", a brief account of the Galeodidae. Sci Prog, NS 3:1-27.

Bernini F (1986) Current ideas on the phylogeny and the adaptive radiations of Acarida. Boll Zool 53:279-313.

Bernini F, Carnevale G, Bagnoli G, Stouge S (2002) An Early Ordovician mite (Acari: Oribatida) from the island of Öland, Sweden. In: Bernini F, Nannelli R, Nuzzaci G, Lillo E de (eds), Acarid Phylogeny and Evolution. Adaptations in Mites and Ticks. Kluwer Academic Publishers, The Netherlands, pp 45-47.

Börner C (1902) Arachnologische Studien (II und III). Zool Anz 25:433-466.

(C) 2007 The Authors J Zool Syst Evol Res (2008) 46(1), 1-18 Journal compilation (c) 2007 Blackwell Verlag, Berlin
Börner C (1904) Beiträge zur Morphologie der Arthropoden. I. Ein Beitrag zur Kenntnis der Pedipalpen. Zoologica 42:1-174.

Boxshall GA (2004) The evolution of arthropod limbs. Biol Rev 79:253-300.

Cambridge OP (1876) On a new order and some new genera of Arachnida from Kerguelen's Land. Proc Zool Soc Lond 1876:258265.

Canestrini G (1891) Abbozzo del sistema acarologico. Attidel R. Istituto Veneto di Scienze, Lettere ed Arti 7:699-725.

Carpenter GH (1903) On the relationships between the classes of the Arthropoda. Proc Roy Irish Acad 24B:320-360.

Chen J-Y, Waloszek D, Maas A (2004) A new 'great-appendage' arthropod from the Lower Cambrian of China and homology of chelicerae and raptorial antero-ventral appendages. Lethaia 37: 3-20.

Claridge MF, Lyon AG (1961) Lung-books in the Devonian Palaeocharinidae (Arachnida). Nature 191:1190-1191.

Coddington JA, Giribet G, Harvey M, Prendini L, Walter D (2004) Arachnida. In. Cracraft J, Donoghue MJ (eds), Assembling the Tree of Life. Oxford University Press, Oxford, pp 296-318.

Condé B (1996) Les Palpigrades, 1885-1995: acquisitions et lacunes. Rev suisse Zool hors serie:87-106.

Coons LB, Alberti G (1999) Acari - Ticks. In: Harrison FW (ed.), Microscopic Anatomy of Invertebrates, Vol. 8b. Wiley -Liss, New York, pp 267-514.

Cruickshank RH (2002) Molecular markers for the phylogenetics of mites and ticks. Syst Appl Acarol 7:3-14.

Dahl F (1911) Die Hörhaare (Trichobothrien) und das System der Spinnentiere. Zool Anz 37:522-532.

Dubinin WB (1957) New system of the superclass Chelicerata. Byull Mosk Obshch Ispyt, priorody, biol 62:25-33 [in Russian with English summary].

Dubinin WB (1959) Subtype Chelicerophora W. Dubinin nom. nov. and its position in the system. 1. Structural peculiarities of Chelicerophora and their classification. Zool Zh 38:1163-1189 [in Russian with English summary].

Dugès AL (1834) Recherches sur l'ordre des Acariens en générale et la famille des Trombidés en particulier. Ann Sci Nat Zool 1:5-46.

Dunlop JA (1996) Evidence for a sister group relationship between Ricinulei and Trigonotarbida. Bull Brit Arachnol Soc 10:193-204.

Dunlop JA (1999) Poecilophysidea: a forgotten arachnid order illustrating a forgotten phylogenetic hypothesis. Newsl Brit Arachnol Soc 85:4-6.

Dunlop JA (2000) The epistomal-labral plate and lateral lips in solifuges, pseudoscorpions and mites. Ekológia (Bratislava) 19(Suppl. 3):67-78.

Dunlop JA (2002) Ernst Robert Abendroth's contribution to arachnid phylogeny. Newsl Bri Arachnol Soc 95:3-4.

Dunlop JA (2006) New ideas about the euchelicerate stem-lineage. In: Deltshev C, Stoev P (eds), European Arachnology 2005. Acta zoological bulgarica Suppl. 1:9-23.

Dunlop JA, Arango CP (2005) Pycnogonid affinities: a review. J Zool Syst Evol Res 43:8-21.

Dunlop JA, Wunderlich J, Poinar GO Jr (2004) The first fossil opilioacariform mite (Acari: Opilioacariformes) and the first Baltic amber camel spider (Solifugae). Trans R Soc Edinb: Earth Sci 94:261-273.

Evans GO (1992) Principles of Acarology. C.A.B. International, Wallingford.

Evans GO, Sheals JG, Macfarlane D (1961) The Terrestrial Acari of the British Isles, Vol 1. British Museum (Natural History), London.

Fayers S, Dunlop JA, Trewin NH (2005) A new early Devonian trigonotarbid arachnid from the Windyfield chert, Rhynie, Scotland. J Syst Palaeont 2:269-284.

Firstman B (1973) The relationship of the chelicerate arterial system to the evolution of the endosternite. J Arachnol 1:1-54.

Giribet G, Edgecombe GD, Wheeler WC, Babbitt C (2002) Phylogeny and systematic position of Opiliones: a combined analysis of chelicerate relationships using morphological and molecular data. Cladistics 18:5-70.

Grandjean F (1935) Observations sur les Acariens ( $1^{\text {re }}$ série). Bull Mus Nat Hist Nat 7:119-126. 
Grandjean F (1936a) Observations sur les Acariens ( ${ }^{e}$ série). Bull Mus Nat Hist Nat 8:84-91.

Grandjean F (1936b) Un acarien synthétique: Opilioacarus segmentatus With. Bull Soc Hist Nat Afr N 27:413-444.

Grandjean F (1954) Étude sur les palaeacaroides (Acariens, Oribates). Mém Mus Nat Hist Nat Paris, Sér A Zoologie 7:179-274.

Grandjean F (1957) L'infracapitulum et la manducation chez les Oribates et d'autre Acariens. Ann Sci Nat, Zool 19:233-281.

Grandjean F (1970) Stases. Actinopiline. Rappel de ma classification des Acariens en 3 groupes majeurs. Terminologie en Soma. Acarologia 11:796-827.

Grasshoff M (1978) A model of the evolution of the main chelicerate groups. Symp Zool Soc Lond 42:273-284.

Haller G (1881) Die Mundtheile und systematische Stellung der Milben. Zool Anz 4:380-386.

van der Hammen L (1961) Description of Holothyrus grandjeani nov. spec., and notes on the classification of the mites. Nova Guinea, Zool 9:173-194.

van der Hammen L (1976) Glossary of Acarological Terminology. Vol. 2. Opilioacarida. Dr. W. Junk bv Publishers, The Hague.

van der Hammen L (1977a) A new classification of the Chelicerata. Zool Meded 51:307-319.

van der Hammen L (1977b) The evolution of the coxa in mites and other groups of Chelicerata. Acarologia 19:12-19.

van der Hammen L (1980) Glossary of Acarological Terminology. Vol 1. General Terminology. Dr. W. Junk bv Publishers, The Hague.

van der Hammen L (1989a) An Introduction to Comparative Arachnology. SPB Academic Publishing bv, The Hague.

van der Hammen L (1989b) Glossary of Acarological Terminology.

Vol. 3. Holothyrida. SPB Academic Publishing bv, The Hague.

Harvey M (2002) The neglected cousins: what do we know about the smaller arachnid orders? J Arachnol 30:357-373.

Hoffmann A (1988) Animales desconocidos: relatos acarologicos. La Ciencia desde Mexico 60, Fondo de Cultura Economica, Secretaria de Educacion Publica, Mexico, pp 129.

Jager M, Murienne J, Clabaut C, Deutsch J, Le Guyader H, Manuel M (2006) Homology of arthropod anterior appendages revealed by Hox gene expression in a sea spider. Nature 441:506-508.

Johnston DE (1982) Acari. Opilioacariformes. Parasitiformes. In: Parker SP (ed.), Synopsis and Classification of Living Organisms. Vol. 2. McGraw Hill, New York, pp 111-117.

Kaestner A (1952) Zur Entwicklungsgeschichte des Prosoma der Solifugen. Zool Anz 148:156-168.

Kaiser T, Alberti G (1991) The fine structure of the lateral eyes of Neocarus texanus Chamberlin and Mulaik, 1942 (Opilioacarida, Acari, Arachnida, Chelicerata). Protoplasma 163:19-33.

Karaman IM (2005) Evidence of spermatophores in Cyphophthalmi (Arachnida, Opiliones). Rev Suisse Zool 112:3-11.

Karg W (2006) The systematics of Parasitiformes, especially of Gamasina Leach (Acarina), with new species from Ecuador. Mitt Mus Nat kd Berl, Zool Reihe 82:140-169.

Karsch F (1892) Ueber Cryptostemma Guér. als einzigen recenten Auslaüfer der fossilen Arachnoideen-Ordnung der Meridogastra Thor. Berlin Entomol Z 37:25-32.

Kethley J (1982) Acariformes. In: Parker SP (ed), Synopsis and Classification of Living Organisms. McGraw Hill, New York, Vol. 2, pp 117-145.

Klausnitzer B, Richter K (1981) Stammesgeschichte der Gliedertiere Die Neue Brehm-Bücheri, A. Ziemsen Verlag, Witenberg Lutherstadt.

Klompen JSH (1992) Comparative morphology of argasid larvae (Acari: Ixodida: Argasidae), with notes on phylogenetic relationships. Ann Entomol Soc Amer 85:541-560.

Klompen JSH (2000) Prelarva and larva of Opilioacarus (Neocarus) texanus (Chamberlin and Mulaik) (Acari: Opilioacarida) with notes on patterns of setae and lyrifissures. J Nat Hist 34:1977-1992.

Klompen JSH (2003) Prelarva and larva of Opilioacarus (Neocarus) texanus (Chamberlin and Mulaik) (Acari: Opilioacarida) with notes on the pattern of setae and lyrifissures. J Nat Hist 34:19771992.

Klompen H, Grimaldi D (2001) First Mesozoic record of a parasitiform mite: a larval argasid tick in Cretaceous amber (Acari: Ixodida: Argasidae). Ann Entomol Soc Amer 94:10-15.
Klompen H, Lekveishvili M, Black IV WC (2007) Phylogeny of parasitiform mites (Acari) based on rRNA. Mol Phylogenet Evol 43:936-951.

Koch CL (1844) Systematische Übersicht über die Ordnung der Zecken. Arch Naturges 10:217-239.

Kramer P (1877) Grundzüge zur Systematik der Milben. Archiv f. Naturgesch, Berlin , 2, 215-247.

Krantz GW (1978) A Manual of Acarology. 2nd edn. Oregon State University Book Stores, Inc, Corvallis.

Kraus O (1976) Zur phylogenetische Stellung und Evolution der Chelicerata. Ent Germ 3:1-12.

Lankester ER (1881) Limulus an arachnid. Qtl J Microscop Sci 23:504548, 609-649.

Leach WE (1815) A tabular view of the external characters of four classes of animals which Linné arranged under Insecta; with the distribution of the genera composing three classes into orders etc. and the descriptions of new genera and species. Trans Linn Soc Lond 11:305-400.

Leach WE (1819) In: Samouelles G (ed.), The Entomologists' Useful Compendium...etc. Thomas Boys, London, pp. 117-133.

Lehtinen PT (1991) Phylogeny and zoogeography of the Holothyrida. In: Dusabek F, Bukva V (eds), Modern Acarology, Volume 2. SPB Academic Publishers, The Hague, pp 101-113.

Lekveishvili M, Klompen H, (2004) Phylogeny of infraorder Sejina. Zootaxa 629:1-19.

De Lillo E, Nuzzaci G, Di Palma A (2005) Sensorial structures in mites and future perspective of research. In: Weigmann G, Alberti G, Wohltmann A, Ragusa S (eds), Acarine Biodiversity in the Natural and Human Sphere. Phytophaga 14:59-91.

Lindquist EE (1984) Current theories on the evolution of major groups of Acari and on their relationships with other groups of Arachnida with consequent implications for their classification. In: Griffiths DA, Bowman CE (eds), Acarology, Vol. 1. Ellis Horwood Ltd., Chichester, pp 28-62.

Lindquist EE, Amrine JW Jr (1996) Systematics, diagnoses for major taxa, and keys to families and genera with species on plants of economic importance. In: Lindquist EE, Sabelis MW, Bruin J (eds), Eriophyoid Mites - Their Biology and Control. Elsevier Science B.V., Amsterdam, pp 33-87.

Ludwig M, Alberti G, (1990) Peculiarities of arachnid midgut glands. 11th Intern. Congr. Arachnology, Turku 1989. Acta Zool Fenn 190:255-259.

Maraun M, Heethoff M, Schneider K, Scheu S, Weigmann G, Cianciolo J, Thomas RH, Norton RA (2004) Molecular phylogeny of oribatid mites (Oribatida, Acari): evidence for multiple radiations of parthenogenetic lineages. Exp Appl Acarol 33:183201.

Maxmen A, Brown W, Martindale MQ, Giribet G (2005) Neuroanatomy of sea spiders implies an appendicular origin of the protocerebral segment. Nature 437:1144-1148.

Mégnin P (1876) Mémoire sur l'organisation et la distribution zoologique des Acariens de la famille des Gamasidés. J Anat Physiol 12:288-336.

Michael AD (1901) British Tyroglyphidae.Volume I. The Ray Society, London, pp 291.

Moritz M (1993) Unterstamm Arachnata. In: Gruner H-E (ed), Lehrbuch der Speziellen Zoologie (begr. von A. Kaestner), 4. ed., Bd. 1: Wirbellose Tiere. 4. Teil: Arthropoda. G. Fischer Verlag, Jena, pp 64-442.

Murrell A, Dobson SJ, Walter DE, Campbell NJH, Shao R, Barker SC (2005) Relationships among the three major lineages of the Acari (Arthropoda: Arachnida) inferred from small subunit rRNA: paraphyly of the Parasitiformes with respect to the Opilioacariformes and relative rates of nucleotide substitution. Invert Syst 19:383-389.

Nitzsch CL (1818) In Ersch und Grubers Allgemeine Encyclopaedie, Band 1, Leipzig.

Norton RA (1998) Morphological evidence for the evolutionary origin of Astigmata (Acari: Acariformes). Exp Appl Acarol 22:559-594.

Norton RA, Kethley JB, (1994) Ecdysial cleavage lines of acariform mites (Arachnida, Acari). Zool Scripta 23:175-191. 
Novak T (2005) Notes on spermatophores in Cyphophthalmus duricorius Joseph (Arachnida: Opiliones: Sironidae). Annals Ser Hist Nat 15:277-280.

OConnor BM (1984) Phylogenetic relationships among higher taxa in the Acariformes, with particular reference to the Astigmata. In: Griffiths DA, Bowman CE (eds), Acarology VI, Vol. 1. Ellis Horwood Ltd., Chichester, pp 19-27.

Oudemans AC (1885) Die gegenseitige Verwandschaft, Abstammung und Classification der sogenannten Arthropoden. Tijdschr Nederl Dierk Vereen, Ser 27:50-88.

Petrunkevitch AI (1949) A study of Paleozoic Arachnida. Trans Conn Acad Arts Sci 37:69-315.

Pittard K, Mitchell RW (1972) Comparative morphology of the life stages of Cryptocellus pelaezi (Arachnida, Ricinulei). Graduate Studies 1. Texas Tech Press, Lubbock, Texas.

Pocock RI (1893) On some points in the morphology of the Arachnida (s. s.), with notes on the classification of the group. Ann Mag Nat Hist 11:1-19.

Reuter E (1909) Zur Morphologie und Ontogenie der Acariden mit besonderer Berücksichtigung von Pediculopis graminum. Acta Soc Sci Fenn 36:1-288.

Robinson LE, Davidson J (1913) The anatomy of Argas persicus (Oken, 1818). Part II. Parasitology 6:217-256.

Rockett CL, Woodring JP (1972) Comparative studies of acarine limb regeneration, apolysis and ecdysis. J Ins Physiol 18:2319-2336.

Savory TH (1971) Evolution in the Arachnida. Merrow Publishing Co. Ltd, Watford.

Scholtz G (1998) Cleavage, germ-band formation and head segmentation: the ground pattern of Euarthropoda. In: Fortey RA, Thomas RH (eds), Arthropod Relationships. Chapman \& Hall, London, pp 317-332.

Scholtz G (2001) Evolution of developmental patterns in arthropods the analysis of gene expression and its bearing on morphology and phylogenetics. Zoology 103:99-111.

Schulze P (1932) Ueber die Körpergliederung der Zecken, die Zusammensetzung des Gnathosoma und die Beziehungen der Ixodoidea $\mathrm{zu}$ den fossilen Anthracomarti. Sitz Ab Naturforsch Ges Rostock, Dritte Folge 3:1-23.

Schwendinger PJ, Giribet G (2005) The systematics of the south-east Asian genus Fangensis Rambla (Opiliones: Cyphopthalmi: Stylocellidae). Invertebr Syst 19:297-323.

Selden, P. A., 1992: Revision of the fossil ricinuleids. Trans R Soc Edinburgh: Earth Sci 83:595-634.

Selden PA, Shear WA, Bonamo PM (1991) A spider and other arachnids from the Devonian of New York, and reinterpretations of Devonian Araneae. Palaeontology 34:241-281.

Shear WA (1982) Opiliones. In: Parker SP (ed), Synopsis and Classification of Living Organisms, Vol. 2. McGraw Hill, New York, pp 104-110.

Shear WA, Selden PA, Rolfe WDI, Bonamo PM, Grierson JD (1987) New terrestrial arachnids from the Devonian of Gilboa, New York (Arachnida, Trigonotarbida). Am Mus Novit 2901:1-74.

Shultz JW (1989) Morphology of locomotor appendages in Arachnida: evolutionary trends and phylogenetic implications. Zool J Linn Soc 97:1-56.

Shultz JW (1990) Evolutionary morphology and phylogeny of Arachnida. Cladistics 6:1-38.

Shultz JW (1994) The limits of stratigraphic evidence in assessing phylogenetic hypotheses of recent arachnids. J Arachnol 22:169 172 .

Shultz JW (2000) Skeletomuscular anatomy of the harvestman Leiobunum aldrichi (Weed, 1893) (Arachnida: Opiliones: Palpatores) and its evolutionary significance. Zool J Linn Soc 128:401-438.

Sitnikova LG (1978) The main evolutionary trends in Acari and the problem of their monophyly. Rev Entomol USSR 58:431-457 [in Russian].
Snodgrass RE (1948) The feeding organs of Arachnida, including mites and ticks. Smith Misc Coll 110:1-93.

Talarico G, Palacios-Vargas JG, Fuentes Silva M, Alberti G (2005) First ultrastructural observations on the tarsal pore organ of Pseudocellus pearsei and P. boneti (Arachnida: Ricinulei). J Arachnol 33:604-612.

Telford RH, Thomas MJ (1999) Appendage development in embryos of the oribatid mite Archaegozetes longisetosus (Acari, Oribatei, Trhypochthoniidae). Acta Zool 80:193-200.

Thor S (1928) Über die Phylogenie und Systematik der Acarina, mit Beiträgen zur ersten Entwicklungsgeschichte einzelner Gruppen Teil 13-15. Nyt. Mag.. Naturvid 67:145-210.

Thorell T (1877) Études scorpiologiques. Arachnoidea. Actes Soc Ital Sci Nat 19:86-102.

Thorell T, Lindström G (1885) On a Silurian Scorpion from Gotland. Kungl Sven Vetenskaps 21:1-33.

Uchida T (1966) The interrelationships of the orders in the Arachnida. Proc Jap Soc Syst Zool 2:42-45.

Vázquez MM, Klompen H (2002) The family Opilioacaridae (Acari: Parasitiformes) in North and Central America, with description of four new species. Acarologia 42:299-322.

Vilpoux K, Waloszek D (2003) Larval development and morphogenesis of the sea spider Pycnogonum litorale (Ström, 1762) and the tagmosis of the body of Pantopoda. Arth Struc Develop 32:349-383.

Vizthum H (1943) Acarina. Bronns Klassen und Ordnung der Tierreichs, Band 5, IAbteilung. Arachnoidea, 1. Lieferung. Akademische Verlagsgesellschaft, Leipzig.

Wagner J (1895) Contributions to the phylogeny of the Arachnida. On the position of the Acarina: The so-called Malpighian tubes and respiratory organs of the Arachnida. Ann Mag Nat Hist 15:285-315.

Walossek D, Müller KJ (1998) Cambrian 'Orsten'-type arthropods and the phylogeny of Crustacea. In: Fortey RA, Thomas RH (eds), Arthropod Relationships. Chapman \& Hall, London, pp 139-153.

Waloszek D, Chen J-Y, Maas A, Wang X-Q (2005) Early Cambrian arthropods-new insights into arthropod head and structural evolution. Arth Struc Develop 34:189-205.

Walter DE, Proctor HC (1998) Feeding behaviour and phylogeny: observations on early derivative Acari. Exp Appl Acarol 22:39-50.

Walter DE, Proctor HC (1999) Mites. Ecology, Evolution and Behaviour. CABI Publishing, Wallingford.

Weygoldt P (1998) Evolution and systematics of the Chelicerata. Exp Appl Acarol 22:63-79.

Weygoldt P, Paulus HF (1979) Untersuchungen zur Morphologie, Taxonomie und Phylogenie der Chelicerata. Z f Zool Systematik u. Evol -forsch 17:85-116, 177-200.

Wheeler W, Hayashi CY (1998) The phylogeny of the extant chelicerate orders. Cladistics 14:173-192.

Woolley TA (1961) A review of the phylogeny of mites. Ann Rev Entomol 6:263-284.

Yoshikura M (1975) Comparative embryology and phylogeny of the Arachnida. Kumamoto J Science (Biology) 12:71-142.

Zachvatkin AA (1952) The division of the Acarina into orders and their position in the system of the Chelicerata. Parazit Sborn 14:5-46 [in Russian].

Zissler D, Weygoldt P (1975) Feinstruktur der embryonalen Lateralorgane der Geißelspinne Tarantula marginemaculata C. L. Koch (Amblypygi, Arachnida). Cytobiologie 11:466-479.

Authors' addresses: Jason A. Dunlop, Museum für Naturkunde der, Humboldt-Universität zu Berlin, Invalidenstraße 43, D-10115 Berlin, Germany. E-mail: jason.dunlop@museum.hu-berlin.de; Gerd Alberti, Zool. Institut und Museum der Ernst-Moritz-Arndt Universität Greifswald, Johann-Sebastian-Bach-Straße 11-12, 17489 Greifswald. E-Mail: alberti@uni-greifswald.de 